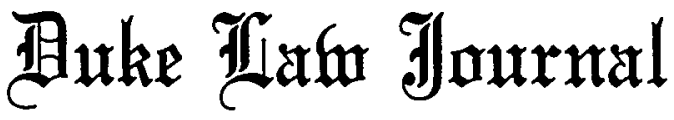

\section{VERTICAL TERRITORIAL RESTRAINTS AFTER SYLVANIA: A POLICY ANALYSIS AND PROPOSED NEW RULE}

\author{
KURT A. STRASSER*
}

I. INTRODUCTION ............................................. 777

II. DISTRIBUTION SYSTEMS ...................................... 785

A. Economic Functions..................................... 785

B. Requirements Necessary for Successful Operation ......... 786

C. Trends in the Structure of Distribution Systems ............ 788

D. Importance of Distribution Systems to Competition ......... 790

III. REASONS FOR TERRITORIAL RESTRAINTS AND JUSTIFICATIONS

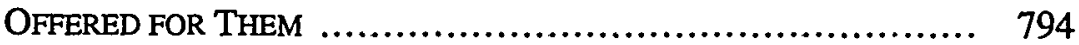

A. Inducement of Pre-sale Dealer Services, Investment and Selling Effort....................................... 795

B. Promotion of Post-sale Services ............................. 806

C. Encouragement of Distributor Loyalty ..................... 813

D. Creation of Entry Barriers .............................. 815

E. Facilitation of Manufacturer Oligopoly Interdependence... 821

F. Other Reasons or Justifications ....................... 827

IV. PROPOSED RULE OF DECISION FOR THE COURTS ................ 830

* Assistant Professor of Law, Mercer University Law School (on leave 1977-1978); Charles E. Merril Fellow, Center for Law and Economic Studies, Columbia University School of Law. B.A. 1969, J.D. 1972, Vanderbilt University.

The author wishes to express his appreciation to Dr. Charles H. Andrews, Chairman of the Economics and Business Administration Department of Mercer University for his continuing help and constructive criticism in preparation of this Article and his reading of preliminary manuscripts. Of course, the author takes sole responsibility for the content of the Article. 
THE FOLLOWING CITATIONS WILL BE USED IN THIS ARTICLE:

Brief for Petitioner, Continental T.V., Inc. v. G.T.E. Sylvania, 97 S. Ct. 2549 (1977) [hereinafter cited as Brief for Petitioner];

Brief for Respondent, Continental T.V., Inc. v. G.T.E. Sylvania, 97 S. Ct. 2549 (1977) [hereinafter cited as Brief for Respondent];

Brief for Respondent in Opposition to the Petition for Certiorari, Continental T.V., Inc. v. G.T.E. Sylvania, 97 S. Ct. 2549 (1977) [hereinafter cited as Brief for Respondent in Opposition to the Petition for Certiorari];

Petition for Certiorari, Continental T.V., Inc. v. G.T.E. Sylvania, 97 S. Ct. 2549 (1977) [hereinafter cited as Petition for Certiorari];

M. Bell, Marketing: ConceptS and Strategy (2d ed. 1972) [hereinafter cited as Bell];

D. Dalrymple \& L. Parsons, Marketing Management: Text and Cases (1976) [hereinafter cited as DaLRYMPLE \& PARSONS];

J. Dirlam \& A. Kahn, Fair Competition: The law and Economics of Antitrust PolicY (1954) [hereinafter cited as DiRLAM \& KAHN];

B. Enis, Marketing Principles: The Management Process (1974) [hereinafter cited as ENIS];

J. HesKett, MaRKeting (1976) [hereinafter cited as HesKETT];

R. Holloway \& R. Hancock, Marketing in a Changing Environment (2d ed. 1973) [hereinafter cited as HoLlowaY \& HANCOCK];

INSIGHTS FOR MARKETING MANAGEMENT (2d ed., G. GELB \& B. GELB eds. 1977) [hereinafter cited as GELB \& GELB];

C. Kaysen \& D. TURner, ANTITRUst Policy: AN ECONomic and Legal ANalysis (1959) [hereinafter cited as KAYSEN \& TURNER];

E. MCCaRTHY, Basic Marketing: A Managerial ApProach (5th ed. 1975) [hereinafter cited as MCCARTHY];

Orderly Marketing, Franchising and Trademark Licensing: Have They Been Routed by Schwinn and Sealy?, in New York State Bar Ass'N, Section on ANTitrust Law, 1968 Antitrust Law Symposium 27 (panel discussion with J. Cohen, I. Millstein, and S. Robinson) [hereinafter cited as SYMPOSIUM].

F. Scherer, Industrial Market Structure and Economic Performance (1970) [hereinafter cited as SCHERER];

D. Thompson, Franchise Operations and ANTitrust (1971) [hereinafter cited as THOMPSON];

Baker, Vertical Restraints in Times of Change: From White to Schwinn to Where?, 44 A.B.A. ANTITRUST L.J. 537 (1975) [hereinafter cited as Baker];

Bork, The Rule of Reason and the Per Se Concept: Price Fixing and Market Division, 74 YALE L.J. 775 (1965) [hereinafter cited as Bork I];

Bork, The Rule of Reason and the Per Se Concept: Price Fixing and Market Division, 75

YALE L.J. 373 (1966) [hereinafter cited as Bork II];

Carstensen, Vertical Restraints and the Schwinn Doctrine: Rules for the Creation and Dissipation of Economic Power, 26 CASE W. RES. L. REV. 771 (1976) [hereinafter cited as Carstensen];

Comanor, Vertical Territorial and Customer Restrictions: White Motor and Its Aftermath, 81 HARV. L. Rev. 1419 (1968) [hereinafter cited as Comanor];

Day, Exclusive Territorial Arrangements Under the Antitrust Laws-A Reappraisal, 40

N.C. L. REV. 223 (1962) [hereinafter cited as Day];

Handler, Recent Antitrust Developments, 112 U. PA. L. Rev. 159 (1963) [hereinafter cited as Handler];

Jenkins, Territorial and Customer Restrictions in Franchise Agreements Under the Antitrust Laws, 2 AKRON L. Rev. 1 (1968) [hereinafter cited as Jenkins];

Jones, The Growth and Importance of Franchising and the Role of Law, 12 ANTITRUST

BuLL. 717 (1967) [hereinafter cited as Jones]; Jordan, Exclusive and Restricted Sales Areas Under the Antitrust Laws, 9 U.C.L.A. L.

REv. 111 (1962) [hereinafter cited as Jordan];

Phillips, Schwinn Rules and the New Economics of Vertical Relationships, 44 A.B.A. 


\section{INTRODUCTION}

Prior to the recent decision in Continental T.V., Inc. v. G.T.E. Sylvania ${ }^{1}$ the law of vertical territorial restraints ${ }^{2}$ began with the 1967 United States v. Arnold Schwinn \& Co. ${ }^{3}$ decision. According to accepted interpretations, the Court in Schwinn held that vertical territorial restraints were per se illegal when they restrain subsequent sales of goods whose title and risk of loss has passed to the purchaser-distributor. However, where the distributor sold goods on consignment, a supplier's restraints would be evaluated with a rule of reason analysis. The decision received extensive commentary and criticism.

Much of the criticism focused on Schwinn's distinction between the applicable rule when goods are sold to the retailer and the rule governing consignment arrangements. No reason related to the purposes of the Sherman Act is given in the decision for the sale-consignment distinction. ${ }^{4}$ Instead, the opinion was based on the "ancient rule" against restraints on alienation and focused on the legal formalities controlling passage of title. ${ }^{5}$ The opinion did not attempt to evaluate the actual effects of these restraints on competition; in fact, it has been argued that there was no basis for concluding that the restraints are less harmful when imposed on an agent or consignee rather than an independent distributor. ${ }^{6}$ The decision identified

ANTITRUST L.J. 573 (1975) [hereinafter cited as Phillips];

Posner, Antitrust Policy in the Supreme Court: An Analysis of the Restricted Distribution, Horizontal Merger and Potential Competition Decisions, 75 CoLuM. L. REv. 282 (1975) [hereinafter cited as Posner];

Preston, Restrictive Distribution Arrangements: Economic Analysis and Public Policy Standards, 30 LAW \& CONTEMP. PROB. 506 (1965) [hereinafter cited as Preston];

Stone, Closed Territorial Distribution: An Opening Question Under the Sherman Act, $30 \mathrm{U}$. CHI. L. REv. 286 (1962) [hereinafter cited as Stone];

Zimmerman, Distribution Restrictions After Sealey and Schwinn, 12 ANTITRUST BULL. 1181 (1967) [hereinafter cited as Zimmerman];

Note, Vertical Territorial and Customer Restrictions in the Franchising Industry, 10 Colum. J.L. \& Soc. PROB. 497 (1974) [hereinafter cited as Columbia Note];

Note, Restricted Channels of Distribution Under the Sherman Act, 75 HARv. L. REv. 795 (1962) [hereinafter cited as Harvard Note];

Note, Exclusive Territorial Arrangements and the Antitrust Laws, 39 IND. L.J. 785 (1964) [hereinafter cited as Indiana Note];

Note, The Resurgence of the Exclusive Territorial Distributorship as an Antitrust Problem, 40 MinN. L. REv. 853 (1956) [hereinafter cited as Minnesota Note].

1. 97 S. Ct. 2549 (1977).

2. Vertical territorial restraints are agreements between parties on different levels of a distribution system which establish geographical restrictions upon the sale of the manufacturer's product by distributors or retailers. See generally Harvard Note.

3. 388 U.S. 365 (1967).

4. Posner 296.

5. Baker 537-38.

6. See, e.g., Note, Territorial and Customer Restrictions: A Trend Toward a Broader Rule of Reason?, 40 GEO. WASH. L. REV. 123, 142-43 (1971). 
several factors which are relevant to a determination of reasonableness in a consignment situation and it has been argued that these factors should have been considered in evaluating the legality of the restraint in a sale situation as well. ${ }^{7}$ To the extent that $S c h w i n n$ required a true agency and not simply a juggling of the formal passage of title, the opinion applied a different rule to different circumstances, with different economic functions and risks assumed by the parties to the restraints. ${ }^{8}$ The most troubling aspect of the saleconsignment distinction in Schwinn was the inconsistency of its use within the decision. The Court found that the distribution program's net effect was to "preserve and not damage competition"9 but, where title had passed, it was "obviously destructive of competition." 10 This inconsistency leads to the conclusion that the decision was not based on an evaluation of the competitive realities.

The Schwinn Court may have implicitly assumed that such an evaluation was simply not possible in cases of this kind if a rule of reason analysis was used. To reach a decision in Schwinn based on a rule of reason analysis would have required the Court to evaluate twenty-three volumes of transcript in a sixty day period. Under these circumstances, it is not surprising that the Court opted for a per se rule. ${ }^{11}$

7. See, e.g., Columbia Note 503. The four factors identified were: the availability of substitutes to retailers and distributors, whether the distributors handle other competing brands, whether price fixing is involved, and whether "competition made necessary the challenged program." Schwinn, 388 U.S. at 381-82.

8. Symposium 37-39 (remarks of Mr. Turner). See also McLaren, Territorial and Customer Restrictions, Consignments, Suggested Resale Prices, and Refusals to Deal, 37 A.B.A. ANTITRUST L.J. 137, 145 (1968); Zimmerman 1188-89.

A recent extended discussion of the rules dealing with vertical restraints has argued that this is what the Schwinn Court intended and that such a distinction is part of the dynamic analysis which has been and should be part of the applicable rules in this area. Carstensen 830, 846-49. However, even Professor Carstensen concedes that if the Court was applying the standard of functional independence which he advocates it erred in applying this standard in the Schwinn case. Id. 848-49. This writer is skeptical that such a standard was adopted in the Schwinn case at all. Professor Carstensen argues that the lower courts have developed, although not articulated, three criteria for determining the policy toward vertical restraints, balancing static and dynamic analysis to evaluate competitive impact of restraints. The second of these would permit efficiency-justified restraints only if the restraining firm is a new entrant or is failing or if the firm restrained is functionally independent. Id. 846-47. Such a criterion is appealing as a theoretical proposition although applying a definition of functional independence in particular cases is practically impossible.

9. Schwinn, 388 U.S. at $381-82$.

10. Id. at 379. Pollock; The Schwinn Per Se Rule: The Case for Reconsideration, 44 A.B.A. ANTITRUST L.J. 557, 562 (1975) discusses this inconsistency. This Article also collects many of the other objections that have been raised to Schwinn.

11. McLaren, Marketing Limitations on Independent Distributors and Dealers-Prices, Territories, Customers, and Handling of Competitive Products, 13 ANTITRUST BuLL. 161, 16869 (1968). It has also been noted that one result of the Expediting Act, 15 U.S.C. $\$ \S 28-29$ (1970), which permits the government to appeal directly to the Supreme Court from the trial court in certain cases, has been to remove one level of appellate evaluation of the case from the ultimate decision-maker. See, e.g., McLaren, supra note 8, at 143-44. 
The decision was also criticized for failing to protect the small businessman. In permitting vertical restraints to be evaluated by a rule of reason in the consignment situation, the decision clearly encouraged distribution through consignment rather than sale arrangements. However, only the relatively well-financed company or the larger company with greater access to capital markets would have been able to take advantage of this rule. ${ }^{12}$ It has also been argued that the decision encouraged large, well-financed businesses to integrate vertically, producing anticompetitive effects. There is serious question, however, whether businesses would be likely to take such action, or whether anticompetitive effects would necessarily result. ${ }^{13}$ Whatever the merits of this debate, Schwinn chose immediately after the decision to integrate distribution functions into its manufacturing operations. ${ }^{14}$ Certainly the Schwinn decision was difficult to support as one favoring small business.

The Schwinn rule was also somewhat surprising in that the government had not asked for a per se rule ${ }^{15}$ and its merits were neither briefed nor argued to the Court. ${ }^{16}$ The previous literature had almost unanimously advocated a rule of reason approach. ${ }^{17}$ Furthermore, the opinion did not adopt the analogies to either resale price maintenance or horizontal market division used by the government in prior consent decrees. ${ }^{18}$ The Schwinn case therefore illustrates that the Court had no theory of what result it was trying to reach in dealing with vertical territorial restraints and no basis for

12. Symposium 51-52 (remarks of Mr. Pollock). See also B. Bock, ANTITRUST IsSUES IN Restricting Sales, TerRitories and OutLets 35-36 (Nat'l Ind. Conf. Bd., Studies in Business Economics, No. 98, 1967); Jenkins 18; Note, supra note 6, at 143-44.

13. See text accompanying notes $236-43$ infra.

14. Keck, Alternative Distribution Techniques-Franchising, Consignment, Agency, and Licensing, 13 ANTITRUST BULL. 177, 189 (1968).

15. Symposium 30-31. It has been contended that the government even conceded in oral argument that a rule of reason analysis was appropriate. Keck, supra note 14, at 177 n.3.

16. Pollock, supra note 10 , at 565 . The Court's inexperience in dealing with rules governing these kinds of restraints is demonstrated by the result in White Motor Co. v. United States, 372 U.S. 253, 261-63 (1963), in which the Court declined to impose a per se rule because it could not gauge the competitive impact of a vertical restraint on the basis of the evidence before it. The Sixth and Seventh Circuit, however, read the case as an explicit rejection of the per se rule. See Sandura Co. v. FTC, 339 F.2d 847, 854 (6th Cir. 1964); Snap-On Tools Corp. v. FTC, 321 F.2d 825, 831 (7th Cir. 1963).

17. Day 223 n.2; Pogue, Vertical Restrictions on Price, Territory and Customers-The Certainty of Uncertainty, 29 OHı ST. L.J. 272, 288 (1968).

18. The government had previously argued that these restraints were per se illegal, basing the argument on analogies to resale price maintenance and horizontal market division. See, e.g., Indiana Note 797-98. It has been pointed out that these analogies are not particularly appropriate and that it would also be possible to analogize to boycotts, restraints on agents, conscious parallelism and vertical integration. Because "all such arguments . . . only tend to perpetuate doctrine that may not have been especially well examined at birth . . .," there is a need for a fresh analysis of the "economic question." Stone 292-93. It is the purpose of this Article to ree. amine this "economic question." 
the rules and distinctions adopted. ${ }^{19}$ The lower courts applying Schwinn were hopelessly confused by this lack of theory and competitive impact assessment. A great many exceptions to the per se rule were created, ${ }^{20}$ and only a few courts applied it strictly. ${ }^{21}$

According to one analysis:

The cases discussed suggest that when courts are confronted by territorial restrictions which are vertical in nature and are used for 'valid legitimate business objectives,' they will interpret Schwinn as narrowly as possible in order to validate the restrictions. Some courts have rejected the per se illegality interpretation of Schwinn outright, by holding that vertical territorial restraints are illegal only if the franchisor is 'firm and resolute' in enforcing the restrictions. Other courts have been willing to consider the validity of vertically imposed restraints related to quality control and the necessity of protecting the public from dangerous products. Some courts have softened the rigidity of the per se approach by generous interpretations of primary responsibility agreements. ${ }^{22}$

While it is not surprising when there occurs some softening around the edges of a per se rule, ${ }^{23}$ the softening of Schwinn was so great that one may

19. Posner 297. Professor Posner extends this conclusion to cover areas of antitrust other than vertical territorial restraints.

20. See, e.g. , Good Investment Promotions, Inc. v. Corning Glass Works, 493 F.2d 891 (6th Cir. 1974); Colorado Pump \& Supply Co. v. Febco, Inc., 472 F.2d 637 (10th Cir.), cert. denied, 411 U.S. 987 (1973); Tripoli Co. v. Wella Corp., 425 F.2d 932 (3d Cir.), cert. denied, 400 U.S. 831 (1970). See generally Robinson, Recent Antitrust Developments: 1974, 75 Colum. L. Rev. 243, 270-81 (1975); Columbia Note 505-12; Note, supra note 6, at 127-37; Note, Territorial Restrictions Under the Sherman Act: Confusion in the Aftermath of Schwinn, 47 Miss. L.J. 239 (1976).

21. See, e.g., Copper Liquor, Inc. v. Adolph Coors Co., 506 F.2d 934 (5th Cir. 1975); Adolph Coors Co. v. FTC, 497 F.2d 1178 (10th Cir. 1974), cert. denied, 419 U.S. 1105 (1975); United States v. Glaxo Group, Ltd., 302 F. Supp. 1 (D.D.C. 1969), rev'd on other grounds, 410 U.S. 52 (1973). See also authorities cited in note 20 supra.

22. Columbia Note 511. This quote was written prior to the decision in Sylvania. This confusion is well illustrated by two recent Ninth Circuit decisions. In Noble v. McClatchy Newspapers, 533 F.2d 1081 (9th Cir. 1975), vacated and remanded, 97 S. Ct. 2966 (1977) (vacated in light of Sylvania), the circuit court applied the per se rule of Schwinn to newspaper distribution routes with the following language: "As we read the Schwinn opinion, manufacturers may avoid the per se rule only by vertical integration or adoption of agency or consignment methods of distribution. Manufacturers who wish to enjoy the advantages of distribution through independent entrepreneurs must be prepared to accept the burdens of Schwinn." 533 F.2d at 1088. However, several months later in Edwin K. Williams \& Co., Inc. v. Edwin K. Williams \& Co.-East, 542 F.2d 1053 (9th Cir. 1976), cert. denied, 97 S. Ct. 2973 (1977), the court held that an exception would be made for bookkeeping services and seminars under the Schwinn rule stating: "A sale under Schwinn must be made 'with no strings attached'; a trade name license requires that the licensee attach 'strings,' that is, the title to his name and some dominion and risk over what he does transfer-his reputation. Schwinn does not apply here." 542 F.2d at 1062. While the cases are factually distinct, the attitude of the Ninth Circuit toward questions of vertical territorial restraint as seen in these two decisions is clearly not consistent.

23. The Per Se Rule, 38 A.B.A. ANTITRUST L.J. 731, 784 (1969) (report of special subcom- 


\section{question whether a per se rule actually existed. ${ }^{24}$}

As a result of this confusion among the lower courts, there was great dissatisfaction among commentators with the Schwinn rule. Professor Posner noted that judicial rule-making in this area by the Court had not met the standards of a coherent theoretical basis of antitrust liability, and had not produced a reasonably precise and objective rule that limited the purely personal values or preferences of judges in deciding cases. ${ }^{25}$ Several proposals for change were also advanced in Congress. ${ }^{26}$

mittee of the Sherman Act Committee of the American Bar Association). See also Sadd, Territorial and Customer Restrictions After Sealey and Schwinn, 38 U. CINN. L. REv. 249, 250 (1969).

24. It has been suggested that a manufacturer by using these exceptions could in fact secure the practical effects of virtually any restraint he wished. Keck, supra note 14, at 182-84; McLaren, supra note 11 , at 171; Pogue, supra note 17 , at 283-85.

Robinson, supra note 20 , at 272 notes the scholarly criticism of Schwinn and then continues:

More surprising, however, is the rough treatment accorded the decision by the lower courts. One would ordinarily expect an authoritative determination by the Supreme Court to be followed obediently irrespective of its logical persuasiveness. Schwinn, however, has not received such deference. Evidently recognizing that a total prohibition of restraints on alienation would produce unpalatable results, judges have struggled to distinguish or limit Schwinn in ways that are a tribute to judicial ingenuity.

The same article later notes that "[t]he cases that have unqualifiedly applied Schwinn's per se rule to strike down post-sale restraint on alienation are relatively few in number." Id. 274 n.200. The author then cites four such cases and one patent misuse case. He adds to this list two cases in which the courts said they followed Schwinn's per se rule but which also involved price fixing.

25. Posner 282-83. This conclusion is particularly applied to distribution cases cited at pages 285-97 of Posner's Article.

26. S. 3421, 94th Cong., 2d Sess. (1976) would have made vertical territorial restraints per se legal in the soft drink industry if three conditions were met: first, the product was in free and open competition with products of the same general class manufactured, distributed and sold by others; second, the restricted party was in free and open competition with vendors of other products of the same general class; and third, the restricting party retained control over the nature and quality of the product in accordance with the provisions of the trademark act of 1946. The bill appears to be in response to the FTC's 197 I complaints against eight major soft drink companies and in response to the decision in United States v. Topco Assocs., 405 U.S. 596 (1972). This bill is a successor to S. 978, 93d Cong., Ist Sess. (1973), which was passed by the Senate in 1973, 119 CoNG. Rec. 18946 (1973), but which died in the House. For more discussion of its terms, see Columbia Note 516.

H.R. 6684, 94th Cong., 2d Sess. (1976) would have made vertical territorial restraints in the soft drink and trademark food products industries not subject to a rule of reason analysis unless this rule of reason were applied after an independent examination of the competitive realities. This bill was a composite of a number of earlier bills introduced in the 94th Congress on this subject. They fall into two general categories: one, those bills modeled after H.R. 5590, 94th Cong., Ist Sess. (1975), which make these restraints per se legal if the three conditions are met (H.R. 5590 manifested a conscious willingness to sacrifice intrabrand competition if interbrand competition remained; this per se legality has not survived into the present H.R. 6684) and two, H.R. 4978, 94th Cong., 1st Sess. (1975), and H.R. 5340, 94th Cong., 1st Sess. (1975), which contained provisions substantially similar to the present H.R. 6684. For further information on H.R. 6684, see REPORT OF THE COMM. ON INTERSTATE AND FOREIGN COMMERCE OF THE HOUSE of Representatives, Exclusive Territorial Franchise ACT, H.R. Rep. No. 94-1230, Part I, 94th Cong., 2d Sess. (1976). 
On June 23, 1977, the Supreme Court in Sylvania overruled Schwinn and held that vertical territorial restraints are now to be tested by the rule of reason. ${ }^{27}$ Defendant Sylvania had used a saturation distribution system prior to 1962 under which it franchised virtually all who wished to handle its products. Its national share of the television set market had declined to a level between one and two percent and it had become dissatisfied with this share. In 1962 Sylvania changed to a selective distribution system under which it would franchise only selected retailers, would deal directly with those franchised and would restrict its retailers to sales from specified locations. It was this location restriction that was the subject of the suit before the Court. ${ }^{28}$ From the change of distribution system in 1962 until the suit in 1965, Sylvania's market share increased to a level of four to six percent and its competitive position improved; the parties disagreed on whether this improvement was caused by the change, but the Court stated that the change "appears to have been successful"' in increasing market share. ${ }^{29}$ The purpose behind the location restriction was to "space" dealers. This would allow dealers some "elbow room" and would ensure that Sylvania's competitive effort would be expended against other brands rather than against other Sylvania televisions. Sylvania argued that this was necessary to induce sufficient dealer pre-sale selling effort; ${ }^{30}$ plaintiff Continental argued, and the Court agreed, that the policy would do this by decreasing intrabrand competition. ${ }^{31}$

The breakdown in relations which led to the suit began when Continental sought a Sylvania franchise for a new store it was opening in Sacramen-

Previously, "several bills which would permit the assignment of 'protected' territories in automobile dealer franchise contracts have been introduced during recent sessions of Congrcss, but none has been enacted." Day 245 n.79. This footnote details the specific provisions introduced.

In 1965 a bill was introduced in the Senate, S. 2549, 89th Cong., 1st Sess. (1965), to legalize vertical territorial restraints generally if conditions substantially similar to those contained in $S$. 3421 were met. This legislation was not enacted. See B. BocK, supra note 12, at 36-37, and Jenkins 9-11 for a general discussion of this bill. See also H.R. 733, 95th Cong., 1st Sess. (1977) (provisions similar to H.R. 6684 supra).

27. Questions concerning vertical territorial restraints were also before the court in Noble v. McClatchy Newspapers, 533 F.2d 1081 (9th Cir. 1975), vacated and remanded, 97 S. Ct. 2966 (1977) (vacated in light of Sylvania).

28. The claims by Continental had originally included price fixing and a tort claim for malicious injury to business; the jury found for Sylvania on these claims. See Petition for Certiorari 118 (Appendix B, District Court Findings of Fact No. 6).

29. Sylvania, $97 \mathrm{~S}$. Ct. at 2552 . Continental had argued that there was no proof that the change caused this improvement, citing testimony from Sylvania's expert witness. Brief for Petitioner 52-53. Sylvania argued that the improvement was a result of the change and the location restriction. Brief for Respondent 10.

30. Brief for Respondent in Opposition to the Petition for Certiorari 5-6; Brief for Respondent 8.

31. Sylvania, 97 S. Ct. at 2552. See generally Petition for Certiorari 4; id. 119 (Appendix B, District Court Findings of Fact No. 7); Brief for Petitioner 6. 
to. ${ }^{32}$ Sylvania argued that its denial of this request was justified because Sylvania's market share in Sacramento was thirteen percent-well above its Northern California average of five percent-therefore causing Sylvania concern about saturation of the Sacramento market. ${ }^{33}$ The district court found that Sylvania denied the Continental request for a Sacramento franchise because it acceded to the objection of its existing Sacramento franchise, although Sylvania continued to contest this conclusion in its brief before the Supreme Court. ${ }^{34}$ In response to Sylvania's denial of a franchise, Continental transshipped Sylvania products from its franchised locations to its Sacramento store and sold them there. Sylvania's credit extending affiliate, John P. Maguire Company, then reduced Continental's credit line from $\$ 300,000$ to $\$ 50,000$ and later terminated all credit arrangements with Continental when Continental stopped making payments to Sylvania in response to the credit reduction. In addition, Maguire brought suit, repossessed all Continental inventory and notified another supplier and Continental's bank of these actions; at this time Continental admitted owing Sylvania approximately $\$ 62,000$ which was not secured. ${ }^{35}$ While Sylvania argued that this was justifiable action by a third party based on credit history, ${ }^{36}$ the district court found that in fact these actions were taken to enforce compliance with the location restriction. ${ }^{37}$ Judgment in favor of Continental was based on the jury's literal application of Schwinn to Continental's counterclaim against Maguire, which alleged the illegality of Sylvania's location clause under the Sherman Act. The court of appeals, en banc, reversed, holding that Sylvania was distinguishable on the facts, and that a rule of reason analysis was required. ${ }^{38}$

32. Sylvania had argued that Continental was retaliating for its decision to grant a franchise to one of Continental's San Francisco competitors, although this argument does not appear to have been relied on or used extensively. Continental did use its buying power to try to prevent the granting of this competitive franchise. Sylvania, $97 \mathrm{~S}$. Ct. at 2552; Petition for Certiorari 121 (Appendix B, District Court Findings of Fact No. 10). Sylvania justified granting the competitive San Francisco franchise because its market share there was only $2.5 \%$, half its Northern California average, and denying the Sacramento franchise to Continental because Sylvania's market share there was $13 \%$-well above both averages. Brief for Respondent 15 n. 12 .

33. Brief for Respondent 15 n. 12 .

34. Petition for Certiorari 123 (Appendix B, District Court Findings of Fact No. 13). See generally Brief for Respondent $18 \mathrm{n} .14$, reviewing testimony on the subject.

35. Brief for Respondent 15-19.

36. Id. ; Petition for Certiorari 124-25 (Appendix B, District Court Findings of Fact No. 15). The justification focused on a recently discovered criminal record of Continental's principal and a recent history of late payments and large loans by other parties.

37. Petition for Certiorari 126 (Appendix B, District Court Findings of Fact No. 16).

38. A major point of contention between the parties both before the Supreme Court and the court of appeals concerned whether the district court had charged that location clauses are always illegal, or had charged the jury that this clause was illegal if the jury found it to be equivalent to a territorial restraint. See Sylvania, 537 F.2d at 982-87 (Kilkenny, J., dissenting); Brief for Petitioner 18-22, 26; Brief for Respondent 20-22. The instruction as it was actually given is set forth at 537 F.2d at 1006 n.la (Kilkenny, J., dissenting). The Court treated the instruction as charging a per se violation, without discussion, and then overruled the per se rule. 
The Supreme Court first rejected the court of appeals' distinction and held that the Schwinn rule applies to a location clause. Because both the intent and competitive impact, the reduction of intrabrand competition, is the same in each restraint, the Court rejected the proposed distinction and overruled a long line of precedent. ${ }^{39}$ In view of the fact that a television retailer can serve an area with a radius of twenty-five to fifty miles, it seems possible to use a location clause to accomplish the result of an absolute territorial restraint. Presumably much of the recent precedent treating the restraints differently was based more on a recognition of the need for some supplier control in product distribution, given the rule of Schwinn, rather than internal consistency in antitrust policy. ${ }^{40}$

The Court went on to catalogue some potential procompetitive benefits of vertical territorial restrictions, including the inducement of pre-sale and post-sale services and remedy of the "free rider" 41 problem in providing these. ${ }^{42}$ Because these benefits are possible results of the use of these restraints, the Court concluded that a per se rule is not appropriate and overruled Schwinn, ordering that these restraints be evaluated with a rule of reason analysis. The Court recognized that cases of this sort require a determination of how much intrabrand competition must be sacrificed in order to gain an imprecise measure of interbrand competition, but gave no guidance or methodology for the application of this weighing process. ${ }^{43}$ This Article will discuss the functions and needs of distribution systems, analyzing trends in their structure and the reasons for use of vertical territorial restraints. A new rule will then be proposed to structure and guide the process by which trial courts weight intrabrand competition lost against interbrand competition gained so as to permit use of these restraints where their use is likely to be procompetitive and prohibit their use where the results are likely to be anticompetitive.

A word on vocabulary is important. Unless the context indicates otherwise, territorial restraints will be those exclusive territorial restrictions which prohibit sales outside the exclusive territories. Thus, while Sylvania presumably makes the same legal rule applicable to complete territorial restrictions, location clauses and areas of primary responsibility, this Article will use these terms to refer to different kinds of restraints for purposes of clarity. It is also assumed that an exclusive agency arrangement is normally

39. $97 \mathrm{~S}$. Ct. at 2556.

40. Previous decisions, including the final decree in Schwinn itself, had held that location clauses were not subject to the Schwinn rule. Sylvania, 537 F.2d at 991-95. Mr. Justice White, concurring, would have continued this exception. $97 \mathrm{~S}$. Ct. at 2563-69.

41. This is also referred to as "cream skimming." See text accompanying notes 112-15 infra for discussion of this concept.

42. Sylvania, 97 S. Ct. 2560-61; 537 F.2d at 1000-01. See generally Brief for Respondent 8, 44-47.

43. 97 S. Ct. at 2560. 
given by a supplier in exchange for the territorial restraints, and the effects of territorial restraints will be considered when they are used with exclusive dealing arrangements. ${ }^{44}$

\section{DisTRIBUTION SYSTEMS}

\section{A. Economic Functions.}

Suppliers establish and maintain distribution systems because those systems perform real economic functions for them. The basic functions of a distribution system must be accomplished by some entity in each system even though the particular services required may vary according to product or other needs. Changes in the distribution system can reallocate responsibility for functions but cannot abolish the need to have the functions performed..$^{45}$

The first function of any distribution system is to deliver the goods. To accomplish this the system must realize buying, selling, transporting, storing and other transactional and logistical operations. ${ }^{46}$ Second, distribution systems must perform a sorting function. A manufacturer's most efficient production quantity-product mix will quite likely not be the most efficient quantity or mix to be offered to the consumer at the retail level. Thus the distribution system must change the quantity and assortment of the goods offered to meet the consumers' preferences. ${ }^{47}$ In many industries, particularly consumer goods industries, it is necessary to have specialists perform this sorting function. Third, a distribution system must perform pre-sale selling services and post-sale repair and other services. ${ }^{48}$ Of course, the specific

44. The distinction in the text between exclusive agency and exclusive dealing arrangements should be emphasized. In an exclusive agency arrangement, the supplier agrees to sell through only one distributor in a territory, typically in exchange for vertical territorial restraints. Thus, vertical territorial restraints as used in this Article will mean exclusive territorial restraints. Exclusive dealing arrangements restrict the distributor to handling only the products of this supplier. The two restraints can be used together or separately.

A distinction is also frequently made between shopping goods and convenience goods. Convenience goods are those for which it is unlikely that the consumer will shop extensively and, for this reason, sales are usually promoted more by intensive distribution, making them more readily available, than by any kind of vertical restraints. Thus, vertical restraints are likely to be used only for shopping goods. Posner 294; Harvard Note. Such goods are more frequently distributed under a selective distribution or exclusive distribution arrangement. See MCCARTHY 313-15.

45. See Dalrymple \& Parsons 401-34; Holloway \& Hancock 391; McCarthy 306-07. It should be noted that some of the functions can be passed on to the consumer in certain circumstances. Even in this situation the functions are still performed, but they are simply performed by the ultimate consumer.

46. Dalrymple \& Parsons 401-02; MCCARThy 306-07. Heskett 338 organizes the list of functions differently, but includes all the same functions.

47. MCCARTHY 301-02 includes a very clear example in the manufacturing and sale of golf balls and other golfing equipment. See also HollowaY \& HANCOCK 394, 396.

48. MCCARTHY 300-02, 306-07. HollowAY \& HANCOCK 392-96 reviews what services may be needed in what situations. HESKETT 338 refers to this as the facilitating function. See notes 
services needed will vary widely among different products. Fourth, a distribution system must perform risk taking and insurance functions $;^{49}$ the risk that certain products cannot be sold, or cannot be sold profitably or in a timely fashion must be borne by some members of the system or collectively by all the members of the system. In addition, goods must be insured while moving through the system until sold. Finally, distribution systems should provide market information to those with authority and responsibility for pricing and other marketing decisions and should also provide some sales stability for all the members of the system. ${ }^{50}$ While consumer preferences and the product's characteristics will greatly influence the actual services provided by a particular system, these various functions must be performed in all systems.

To perform these functions a distribution system must incur cost. The cost of a distribution system relative to that of its competitors is determined by how efficiently the functions are allocated and performed. ${ }^{51}$ The entities in a distribution system justify their individual and collective existence by adding efficiencies to the distribution system. ${ }^{52}$ To avoid allowing for competitive advantage, rules adopted to regulate vertical territorial restraints should not interfere with performance of the functions of distribution systems at lowest cost.

\section{B. Requirements Necessary for Successful Operation.}

The most important requirement of a distribution system is that it function as a coordinated system rather than as a group of independent businesses. ${ }^{53} \mathrm{~A}$ restricted distribution arrangement, such as a vertical territorial restraint, transfers some of the decision-making authority of one business unit into the control of another business unit. ${ }^{54}$ Such arrangements can help the system operate in a coordinated manner to improve efficiency and profits. ${ }^{55}$ To achieve this coordination all members of the distribution system must be aware of their mutual self-interest and be willing to sacrifice

100-74 infra and accompanying text for a discussion of the effect of vertical territorial restraints on the provision of these services.

49. MCCARTHY 307.

50. Id.

51. Id. 308; THOMPSON 4.

52. HollowaY \& HANCOCK 386-87.

53. "For maximization of channel profits and consumer satisfaction, the channel must act as a unit." Mallen, Conflict and Cooperation in Marketing Channels, in GeLB \& GELB 221. See generally ENIS 490-91; MCCARTHY 307-10; Carstensen 776.

54. Preston 506-07.

55. The object of channel cooperation is maximization of channel profits. It is frequently assumed that every member of the channel has "product market commitment" to the greatest sales of the product. See, e.g., ENIS 458; GELB \& GELB 249. However, the commitment is only to profit maximization and in some circumstances the greatest profits will result from fewer sales at higher prices. In this situation, channel cooperation is used to achieve greatest sales at the higher prices and may also be used to maintain prices. Restraints will not be used where there is no market power but are used only to exploit or create it. Carstensen 777-78. 
some short run individual gain to achieve greater long run individual and group gain. ${ }^{56}$ Retailer indifference to mutual self-interest is reported to be the greatest obstacle to coordinated action; 57 vertical territorial restraints may be used to increase perception of mutual self-interest and to restrain conduct not in accord with it.

In order to achieve coordination and function as a system, a distribution channel must be able to solve intra-channel conflicts. Channel conflict may result from different economic goals of channel members, differing ability to control each others' conduct, different desires for independence and different customer loyalties sought. ${ }^{58}$ Coordination is a function of the ability to resolve channel conflicts and also to convince members of their mutual self-interest. ${ }^{59}$ While channel conflicts may be solved by anarchy, with no leader and no coordination, or by "democracy," where channel members choose a leader and make group decisions, most marketing writers in the area prefer resolution of channel disputes through the efforts of a channel captain. ${ }^{60}$ Such an approach advocates "the management, rather than the minimization, of channel conflict." 61 While the sources of channel leadership power and the means of its exercise may vary, ${ }^{62}$ some source of leadership is necessary for the channel to achieve the cooperation and conflict resolution required for efficient functioning as a total system. Territorial restraints are one source of such channel leadership power in that they affect control and gross margins. Thus, they may be used to improve competitive functioning of distribution systems.

In addition to the requirements of cooperation, conflict resolution and leadership, distribution systems must also retain flexibility to meet dynamic market situations. The demands of the marketing situation can be varied and the most effective distribution system is one which can respond to their changes. ${ }^{63}$ This flexibility is needed to meet both changes in supply of the product and changes in demand for the product. ${ }^{64}$ Paradoxically, the kinds of decisions made in establishing a distribution system tend to be very costly

56. HESKETT 358. Of course, there are antitrust implications both to the realization of this mutual self-interest and the mechanics of maximizing it. These will be discussed in the text accompanying notes $92-253$ infra.

57. BeLl 713; HesketT 356-57.

58. Dalrymple \& Parsons 416; Enis 459.

59. Holloway \& HaNCOCK $387-90$.

60. Enis 459-62; Gelb \& Gelb 245; McCaRThy 307-10; Thompson 41-43.

61. ENIS 462 .

62. "The ability of a manufacturer, wholesaler, retailer or other channel intermediary to exercise channel control may reflect the relative perceived strength of its customer 'franchise,' the combination of supporting activities and margin that it is willing to offer other intermediaries, and the 'stake' that others have in the success of its products, services, or marketing effort." HESKETT 356.

63. Dalrymple \& Parsons 402-03.

64. MCCARTHY 303. 
and difficult to change; selection of a distribution system tends to become a semi-permanent arrangement. This is true both because retail and wholesale facilities, leases and customer patterns are hard to change, and because good working relationships with middle members of the distribution channel are developed only over time and with the expenditure of money. ${ }^{65}$ Thus, the system's flexibility requirements are frequently difficult to meet. One way of retaining flexibility, at least partially, is through the introduction of a dual distribution system. Different distribution channels permit the firm to reach different market segments and the addition of new channels may enable the firm to respond to new or changing market segments. ${ }^{66}$ Beyond this, though, it is difficult for a distribution system to maintain the capability to respond to a changing market situation.

\section{Trends in the Structure of Distribution Systems.}

Distribution systems are usually grouped into three categories, according to their degree of internal cooperation and external structure. First is the traditional channel system with no interrelationship and free and open competition for purchases and sales. ${ }^{67}$ Such systems are flexible but can lead to erratic supply and demand patterns and higher costs. The second type of system is an administered or contractually integrated system. ${ }^{68}$ The degree of control exercised by the controlling element in the system and the way that this control is created and exercised vary greatly. However, the hallmark of such a system is some internal coordination between business entities that are at least partially independent. Such systems account for approximately thirty-seven and one-half percent of all retail sales in the consumer goods field. ${ }^{69}$ Finally, there are vertically integrated systems in which all distribution functions are performed by one business entity; such systems presently account for approximately twenty-six percent of the consumer goods retail sales in the country. ${ }^{70}$ The trend in all distribution systems is away from the completely independent system to one that is

65. MCCARTHY 300. See generally BELL 720 .

66. BeLL 711; DaLRYMPLE \& PARSONS 405-06. HeSKETT 287-88 discusses this topic under the heading "Scrambled Merchandising." Dual distribution channels may also facilitate price discrimination; the causes and effects of such discrimination resulting from vertical territorial restraints will be discussed below.

67. See Holloway \& Hancock 387; McCarthy 311; Thompson 41.

68. THOMPSON 41-43. HollowaY \& HANCOCK 387-90 separates continuous routinized transactions from merchandise line transactions, but both groups tend to fall within this broad category. Continuous routinized transactions involve the sale of the same product or products to the same customers through the same distribution system; typically the system will provide few and standardized pre-sale or post-sale services. Merchandise line transactions involve less standardized sales or products, or frequently changing customers; typically more services are supplied and they are less standardized.

69. MCCARTHY 312.

70. Id. See Holloway \& Hancock 390; McCarthy 311; Thompson 41-43. 
either administered, contractually integrated or integrated through ownership which can achieve internal cooperation and some resulting cost efficiency. ${ }^{71}$ "The inevitable conclusion is that vertical market systems are becoming the principal competitive units in the U.S. distribution system." "72 It therefore appears that, while profit maximization will continue in the future to be the goal, it will be achieved more from organizational change than from technological advance. ${ }^{73}$ Thus, distribution will be an increasingly important point of concern for business enterprise in the United States, thereby increasing the impact of the laws regulating distribution systems.

The new focus on distribution systems as a competitive element is accompanied by a shift in the channel leadership of many industries. In the nineteenth century the location of channel leadership was typically in the wholesaler.$^{74}$ In the twentieth century this leadership shifted to the manufacturer, partly because he could finance distribution operations, and partly because he was larger and more stable. Also, the manufacturer's interest in distribution had increased, since he now needed a greater assurance of larger sales volume to pay for the increased capital investment demanded by modern technology and for the increased inventory required by modern mass marketing. ${ }^{75}$ However, a decided shift has been observed more recently, in that "there is mounting evidence in many industries that the real leadership of many channels rests in the hands of either wholesalers or retailers." ${ }^{, 76}$ Although there is still debate on the matter, respectable predictions indicate that the location of channel leadership is in the process of shifting to the mass retailer, at least in the market for consumer goods. ${ }^{77}$ The focus of marketing is today on mass media advertising, particularly national advertising, and national branding of consumer products which pre-sell the customer, stimulate consumer demand on a national scale and then meet this demand through efficient national distribution. ${ }^{78}$ These marketing trends reinforce the shift away from a manufacturer dominated distribution channel. They also enlarge the market share of nationally advertised goods and frequently require that some sort of cooperative marketing, either through a franchise system or otherwise, be undertaken to achieve the benefits of national advertising and branding.

71. EnIS 463; Heskett 349; MCCARThy 312; Thompson 41. Holloway \& HanCock 392 states that the domination of distribution systems by one firm derives from the desire for control and for the elimination of interfirm dependency. DaLRYMPLE \& PARSONS 406-07 finds a trend toward factory owned wholesalers.

72. MCCARTHY 312.

73. ENIS 490-91. See generally Jones 720 .

74. GelB \& GELB 213-14.

75. Id. 214; MCCARTHY 307.

76. Holloway \& HanCOCK 399.

77. GeLB \& GeLB 215-16.

78. THOMPSON 12-13; Baker 540; Jones 720. Carstensen $774-75$ concludes that the result of modern advertising techniques and technology is a shift of power from the retailer to whatever member of the system has the requisite size to advertise. 
One response to this shifting channel leadership and market demand has been extensive use of franchising. While franchising may take many different forms in different situations, most franchise arrangements share four characteristics. First, the franchisee is an economically dependent but legally independent member of the system. Second, the franchise business is operated with the name and standardization advantages extended by the franchisor. Third, the franchisee's business came into being to sell the franchisor's product or service. Finally, there is typically a formal agreement and continuing relationship between the parties. ${ }^{79}$ Franchising is a way of permitting the smaller manufacturer or smaller retailer to survive in a world of vertically integrated giants in that it permits the franchised business to achieve the advantages of national operation without the expense of a nationally owned organization. ${ }^{80}$ Yet, the controls inherent in a franchise system present a delicate antitrust problem. "The central question confronting both business and the antitrust enforcement agencies . . . is to determine what are the essential elements of the franchise arrangements and what controls and obligations are necessary in order to maintain the essence of the true franchise system." 81

The same problem is presented by vertical distribution restraints generally and territorial restraints specifically. Where the restraints are necessary to establish distribution systems which permit small operators to achieve efficient operation, or encourage competition, they should be permitted; where not necessary, they should be discouraged. In view of modern marketing trends, some restraints will be necessary and justifiable. ${ }^{82}$

\section{Importance of Distribution Systems to Competition.}

Within a given product market each distribution system is competing with every other distribution system, and all products in a given market are

79. ThOMPSON 7-8 gives this as the definition of franchising. See DALRYMPLE \& PARSONS 409-10 for a discussion of the ability of a franchising arrangement to take advantage of national advertising. For information on the extent of franchising, see THOMPSON 30-33; Jenkins 1-4.

80. Jenkins 16-17; Jones 717-21. See generally Distribution Problems Affecting Small Business: Hearings Before the Subcomm. on Antitrust and Monopoly of the Senate Comm. on the Judiciary, 89th Cong., 1st \& 2d Sess. (1965-1966).

81. Jones 727.

82. The view is widely held that some restraints are necessary for survival of nonvertically integrated firms or firms which do not market on a national scale. See THOMPSON 37-40; Bohling, Franchise Terminations Under the Sherman Act: Populism and Relational Power, 53 TEX. L. REV. 1180, 1240 (1975); Jenkins 17-18; Jones 723-25, 738-39; Keck, supra note 14, at 190-91; Zeidman, The Growth and Importance of Franchising-Its Impact on Small Business, 12 ANTITRUST Bull. 1191, 1193-94; Note, Regulation of Franchising, 59 MinN. L. REv. 1027 (1975).

The statement in the text should not be interpreted as justifying these restraints in every situation. Clearly the needs of distribution systems will justify restraints in some circum. stances. Sections III and IV of this Article will be devoted to separating those circumstances where the restraints are justified from those where they are not. 
competing for the purchasing dollar of the ultimate consumer. This is true whether the ultimate consumer is buying for his own end use, or to utilize the product in creating yet another product or surplus. From this perspective the focus of any distribution channel is "[f]rom whom will our ultimate purchasers buy?" 83 The channel's main concern, then, is to function so as to consummate sales with its ultimate purchaser. As discussed above, the channel will be able to do this most efficiently and effectively when it operates as a coordinated unit. Since there is ultimately competition between and among distribution systems, each system will compete with each other system for the sales to the consumer, regardless of the number or structure of the business entitites involved. As Professor McCarthy has pointed out, "[i]n the final analysis, it is channel systems which compete with each other. The battle of the brands, for example, can be seen in a broader context as only a skirmish in the battle between various channel systems." 84

In competing with other distribution systems, each individual distribution system can be no stronger than the component parts of the system. A system which has some weak as well as strong links will of course be less able to compete effectively than a system which has only strong links. The competitive success of the entire system, and hence of each entity in the system, is tied to the functioning of the system as a whole. ${ }^{85}$ Thus each entity in the system has a very strong interest in the way the other entities in the system perform. For example, the manufacturer of a competitive product, which is sold through retailers providing competitive services, will be placed at a disadvantage if his wholesalers do not function as efficiently as those of his competitors, weakeming the distribution system. The retailer will be similarly prejudiced. In this situation the manufacturer and the retailer have a legitimate interest in the performance of the wholesaler. Since each component part of the system is dependent upon the performance of every other part for the system's competitive success, each component has a legitimate interest in the performance of other members. ${ }^{86}$ Each member has a further legitimate interest in the other members' performance because it will affect product demand. Advertising, pre-sale services, postsale services and other aspects of the intermediate handling and ultimate sale of the product all affect overall product demand. In order to protect this

83. BeLL 702.

84. MCCARThY 317.

85. HOLLOWAY \& HANCOCK 392 . Of course, exceptionally strong members of the system could offset the effect of weak members, giving an overall average strength to the system. However, even in this situation, the exceptionally strong member loses a competitive advantage which his strength, standing alone, would give him.

86. Jordan 111-13; Indiana Note 804-05. The word "legitimate" is used here to describe an interest which is other than an anticompetitive one. It is assumed that any business conduct or interest is legitimate if it is not anticompetitive in purpose or result. 
interest, members of the system should be permitted to place some controls on the operation of other members of the system. ${ }^{87}$

The above discussion assumes that there is in fact competition between and among distribution systems. However, if substantial market power exists, resulting in a lack of effective competition, then the members of an individual system do not have nearly as great an interest in each other's performance. There still exists some interest in that the members of the system prefer lower costs which result from a more efficient system. ${ }^{88}$ However, this interest is usually not one that society should protect, since it is usually only a regulator of the amount of excess profits that the firms in this market power situation will be making.

To recognize that an interest exists for which some protection through vertical restraints can be sought when there is effective interbrand competition does not establish that the interest is always paramount. The remaining sections of this Article will consider how much protection should be afforded, in view of both the legitimate needs and the anticompetitive effect of restraints used to accomplish protection.

Before turning to an evaluation of the reasons for restraints and the rules governing restraints, one other aspect of competition in distribution should be mentioned. In addition to the competition between distribution systems discussed above, there is also competition for the business of members of the chain of distribution. Thus a supplier may wish to attract distributors through his favorable policies toward them and a distributor may

87. In Section III, infra, the circumstances under which restraints establishing these controls should be permitted will be discussed, together with the kind of restraints which should be permitted.

A distribution system which performs more effectively can also result in lower costs which yields yet another competitive advantage. See text accompanying note 52 supra.

88. Lower costs will give the firm a greater potential margin between the existing market price and a competitive price and, consequently, permit greater profits. Such lower costs would also increase the pricing flexibility of the firms in this concentrated market. In the extreme case, a pure monopolist maximizes profit in the long run by producing and marketing at a rate of output which has a long run marginal cost equalling marginal revenue. When overall distribution costs are lowered, the whole marginal cost curve is shifted down. Because marginal revenue and demand curves both slope downward to the right, a shift in the marginal cost curve will cause it to intersect the marginal revenue curve further to the right, indicating the possibility of a larger quantity. Thus, the monopolist could choose to manufacture this larger quantity, although selling it would require the lowering of the price as the monopolist moves to the right on the demand curve. This increased flexibility in production decisions would increase the opportunity for the monopolist to maximize profits. See generally C. FERGUSON \& J. GouLD, MiCROECONOMIC THEORY 279-81 \& Ch. 9 (4th ed. 1975). To a lesser extent, this increased flexibility could be used by firms exercising oligopoly but not total monopoly power.

In a particular market situation such lower costs may also lower unit production costs by expanding demand, and hence output, to a point on the long run average cost curve which is lower than at the smaller output. This will occur only where the firm or firms with market power are not operating at sufficient output to achieve lowest long run average costs without the restraints. Where such is the case, society's interest is served by encouraging the lower cost. 
wish to attract the business of a supplier by his sales effort or other services. Such competition will tend to keep excess profits out of the system, or at least reduce them all along the channel. There is less need for this competition if effective interbrand competition exists because excess profits are much less likely. Such competition also tends to make new entry and competitive expansion easier because the new entrant or the expanding business has access to entities which can perform the functions of other members of the chain. Once again, there is less need for this new entry and expansion if interbrand competition exists in the ultimate product market. If there is such competition, there are fewer excess profits and less need for more competitors in the market. Unfortunately, such a legal standard means that conduct which is legal today may not be legal tomorrow-depending on the state of interbrand competition at the time the evaluation is made. ${ }^{89}$ Vertical restraints of the type under consideration in this Article will tend to decrease this competition for business of the members of the chain of distribution.

It is generally accepted, although not universally recognized, that there are social goals and policies underlying the antitrust laws in addition to the policy of economic efficiency. ${ }^{90}$ Thus it has been noted that we favor competition not only because it produces the best economic results, but also as an end in itself, in that competition is "indissolubly linked with the values of free enterprise, equality of economic opportunity, the channeling of the profit motive into socially constructive channels, distributive justice, and the diffusion of economic power."91 Preservation of this competition for the business of the members of the distribution systems is an important value to be weighed in evaluating specific vertical territorial restraints. To the extent that restraints tend to tie members of the chain together too tightly, those restraints must be seriously questioned, chiefly because they

89. See text accompanying notes 182-230 infra for a discussion of entry barriers and foreclosure resulting from vertical territorial restraints.

Professor Carstensen finds a common thread of preservation of independence of distributors and producers throughout the vertical restraint cases; he then points out that such a principle views the market as dynamic and concerns itself with preservation of dynamic characteristics in the market. Carstensen 810-17. In advocating analysis of both the dynamic and static characteristics of markets, his analysis is compatible with that of this Article. This writer believes, however, that there is some question about whether the courts have in fact recognized this principle in the cases.

90. "The propriety of antitrust regulation rests principally on the general social goals of antitrust policy: the preservation of business opportunities for the small entrepreneur, the promotion of diversity and decentralization in private economic decisionmaking, and the deterrence of the concentration of economic power." Bohling, supra note 82, at 1186 . See generally DIRLAM \& KAHN vii, 39, 175, arguing that antitrust laws should reverse the efficiency question and ask only whether the particular rnles interfere with economic efficiency, rather than whether they promote it. For a discussion of the contrary view and reasons supporting it, see Bork I 775-80.

91. Dirlam \& KaHn 39. 
may lead to abusive practices which conflict with the social goals of antitrust policy. Protection from abuse and preservation of competition are important policy goals in this area of the law. Where there is effective interbrand competition, the restraints are not likely to be efficiency-destroying because this would weaken the competitive effectiveness of each individual distribution system. This natural check of the system, however, will not limit the use of practices which are overly restrictive but not efficiency-destroying. Where there is not effective interbrand competition, these restraints should be viewed more restrictively.

\section{REASONS FOR TERRITORIAL RESTRAINTS AND JUSTIFICATIONS OFFERED FOR THEM}

Businessmen may enter into restrictive territorial arrangements for many reasons. Some of these reasons are procompetitive, some are competitively neutral, and some are clearly anticompetitive. This section will survey the reasons why businessmen might enter into these restrictive agreements and evaluate each reason and the justifications offered to support it in light of the procompetitive policy of the antitrust laws.

The basic problem in evaluating territorial restraints is determining how much intrabrand competition is being sacrificed, and how much efficiency or interbrand competition is being gained for that sacrifice. Intrabrand competition exists because customer markets are not discrete and, consequently, retail and other distribution outlets for the same product compete with each other. Territorial restraints make these markets more discrete and thereby reduce intrabrand competition. ${ }^{92}$ Closed territorial restraints reduce intrabrand competition more than exclusive selling arrangements because they raise higher barriers of proximity; ${ }^{93}$ customer allocation clauses would eliminate intrabrand competition entirely. ${ }^{94}$

Just as territorial restraints may weaken or reduce intrabrand competition, it has also been widely observed that they may promote interbrand competition. ${ }^{95}$ These restraints encourage competition primarily by adding

92. Comanor 1422-23; Day 225-26; McLaren, supra note 11, at 161; Zimmerman 1182-83; Minnesota Note; Comment, Vertical Restraints on Territorial Distribution, 37 S. CAL. L. REV. 332, 336 (1964).

93. If a distributor can sell only in a defined territory, he can sell to customers outside that territory only if he can induce them to incur the inconvenience of coming into the territory to buy from him. This inconvenience is a potential barrier to.such sales and is created by the customer's proximity or distance from the distributor.

94. Day 226-27. Customer allocation clauses divide customers, and usually potential customers, among distributors and no distributor may sell to customers allocated to another distributor. Geographic allocation by place of customer's business or residence is one form of such allocation.

95. See, e.g., Day 248-49; Handler 169-70; Harvard Note 813, 827-28; Minnesota Note 853; Comment, supra note 92 , at 337 . It has been argued that the competition thus encouraged is 
to the economic health of competitors and thus encouraging their survival. ${ }^{96}$ Accordingly, the essential test is whether the restraints in question promote interbrand competition sufficiently to outweigh the anticompetitive effects of the loss of intrabrand competition. Basically, one is looking to see "whether this departure from competitive structure within one marketing organization is counterbalanced by an increase in the number of marketing organizations and products available in particular markets or in the vigor of competitive behavior." "97 Given the fact that "vertical ownership integration is both endemic and largely beyond the reach of antitrust controls," the preservation of intrabrand competition may be even more significant, particularly in the presence of substantial product differentiation. ${ }^{98}$ One of the most telling criticisms of the law under Schwinn was that it did not consider that vertical restraints on intrabrand competition which enhance efficiency may be necessary to promote interbrand competition. ${ }^{99}$ The remainder of this section will discuss the reasons for using such restraints, and the following section will evaluate the restraints and propose a new rule for determining their legality.

\section{A. Inducement of Pre-sale Dealer Services, Investment and Selling Effort.}

Territorial restraints are frequently used to encourage pre-sale services and effort on the part of distributors. Such services include advertising, maintenance of showrooms and large inventories, extension of credit, and other promotional and advertising activity. There seems to be little disagree-

non-price competition, frequently called rivalry, and hence should not be promoted. Comanor 1437. While some non-price competition may be encouraged, it seems clear that territorial restraints may also create more competitive market structures which would encourage price competition.

It has also been argued that there is less likelihood of a horizontal conspiracy if these restraints are permitted. Stone 311 . However, because the horizontal conspiracy is illegal irrespective of the rule on territorial restraints, if the parties are willing to engage in one it does not seem likely that these restraints will have much of an effect on such behavior.

96. See text accompanying notes 100-81 infra. Sandura Co. v. FTC, 339 F.2d 847 (6th Cir. 1964), is frequently cited for the proposition that vertical territorial restraints (along with other restraints) can permit a failing company to survive, eventually surmounting its problems and remaining a viable competitor in an otherwise concentrated industry. Snap-On Tools Corp. $v$. FTC, 321 F.2d 825 (7th Cir. 1963), is an of t-quoted example of a court concluding that vertical territorial restraints can induce provision of pre-sale selling services, which are essential to the survival of a manufacturer as a competitive entity.

97. Preston 508. See also Pogue, supra note 17, at 281; Zimmerman 1182-83. It has been argued that courts are simply unable or unsuited to weigh this relative loss or gain. See Bork II 472. This Article attempts to provide guidelines to assist a court in this weighing process.

98. ThompSon 99-100. Day 248-49 notes that resale price maintenance is more restrictive than vertical territorial restraints because it restrains both interbrand and intrabrand competition.

99. Note, supra note 6 , at 143-44. It has been observed that the Schwinn court did not feel able to weigh the relative gain and loss to competition and adopted a rule which did not require such weighing. Part IV, infra, will present a rule designed to accomplish such weighing. 
ment with the proposition that territorial restraints do in fact encourage provision of pre-sale selling services. ${ }^{100}$ To the extent that territorial restraints provide some protection from effective intrabrand competition, they increase distributor margin and provide a fund from which such services can be financed. ${ }^{101}$ Also, the resulting greater margin will encourage more significant dealer investment in advertising, sales facilities and personnel. ${ }^{102}$ It has been argued that a distributor is able to maximize the sales and gross profit per amount of sales effort because these restraints permit him to tailor his sales effort to the local market needs. ${ }^{103}$ Of course, the amount of services required will be largely determined by the characteristics of the product and the amount and kind of sales effort required to sell it. ${ }^{104}$ However, to the extent that suppliers share the public interest in maximum output, they will engage in territorial restrictions only to induce distributor investment and services which would not otherwise be forthcoming. ${ }^{105}$ It would therefore appear that where a product requires point-of-sale services, the provision of those services is one justification for territorial restraints employed in the distribution of the product.

By encouraging more pre-sale services the manufacturer can frequently increase his market penetration, partially because territorial restraints can make the distributor work his territory more intensively. ${ }^{106}$ Because the distributor can make sales only in his territory, and because his profit margins will be related to his total volume of sales, he must develop the

100. See, e.g., Jordan 117-18; Posner 283-84; Preston 511-12; Harvard Note 827-28.

101. Total dollar margins "determine, and may place constraints on, the types of responses that can be made to customer-product needs." HeSKETT 346. See also THOMPSON 107-08; Zimmerman 1182-83.

102. Bork II 430-36.

103. The statement in the text is only partially true, however. Most manufacturers are interested in maximum profits and pursue maximum output only to the extent that they believe it will produce maximum profits. With product differentiation or through the exploitation of market power a manufacturer may be able to increase profits with smaller output sold at higher prices.

However, to the extent that territorial restrictions are used to induce retailer efforts, and hence sales, which would not otherwise be forthcoming, the statement in the text is still partially true. Stone 300 .

104. BELL 696; Handler 165-66. Snap-On Tools Corp. v. FTC, 321 F.2d 825 (7th Cir. 1963), is a frequently cited pre-Schwinn decision involving a situation where provision of point-ofsale services was essential to survival in the product market. The products being sold were mechanics' hand tools and the services needed were direct person-to-person contact between the salesman and the purchasing mechanic. After a full evaluation of the practice and its industry context the court upheld the vertical territorial restraints as being an essential inducement to provision of the requisite point-of-sale services. See id. at $828,832-33$.

105. Jordan 119-20.

106. See Dalrymple \& Parsons 414-16; Harvard Note 828. Preston 513 contains a theoretical model which demonstrates this conclusion as an abstract proposition. The problem with this model concerns the assumptions necessary to make the model workable; when these assumptions are varied and relaxed it has been argued that the result is to "reduce the return from the model to a simple display of analytical elegance." THOMPSON 114. 
sales potential of the territory to realize additional sales. In essence, the distributor may spend his higher margin on seeking out new customers and enticing them to buy.

While these restraints do encourage provision of pre-sale services, they may also be injurious to consumers when used in a market which has little effective interbrand competition. First, the restraints create the consumer price increases necessary to pay for enhanced retailer margins, furnishing the retailer with excess profits. If there is substantial interbrand competition, excess profits of the retailer will be held to a minimum because the competition will bid them out. However, where there is a lack of interbrand competition, perhaps resulting from substantial product differentiation, this increased market penetration will be achieved at a higher consumer price level. ${ }^{107}$ At the very least, the consumer here trades a competition-induced lower price for greater product selection; ${ }^{108}$ at worst, he pays a higher price and will not necessarily receive the greater selection should the distributor pocket the excess rather than utilize it to seek out new customers-a more likely alternative in the absence of effective interbrand competition. If there is interbrand competition, territorial restraints are a way of competing for additional market shares. As such competition, they should be permitted and encouraged. If there is no interbrand competition, territorial restraints may increase price without improving quality of selection.

In addition, a lack of interbrand competition may also result in the selling of more services than buyers wish. Certainly, where interbrand competition exists, operation of the market mechanism should bid out provision of the services which the public does not wish to buy. ${ }^{109}$ The distributor who provides greater services than the public wants, presumably at greater costs than the competitor who is providing only the amount of services desired, will find himself with declining sales because of his higher prices. Eventually, he will lose sales and reduce services to permit price reduction. But where there is no substantial interbrand competition, regardless of the cause, there is no market mechanism to bid out the excess services. Thus the protection from interbrand competition offered by territorial restraints may inundate the public with the sale of these unwanted services. ${ }^{110}$ Vertical territorial restraints to induce provision of pre-sale

107. Comanor 1430. In this circumstance, the increased distributor margins are being used to seek out customers whom it would not be economical to pursue if there were interbrand competition. This conclusion was also reached by Preston 518. The difficulties with his analysis are discussed in note 106 supra.

108. Columbia Note 512-15. See generally E. Chamberlain, The Theory of Monopolistic COMPETITION (1933); J. Robinson, THE ECONOMICS OF IMPERFECT COMPETITION (1938).

109. HESKETT 346-47. This discussion does not include provision of retail level services as a type of product differentiation, which will be discussed below.

110. Comanor 1429-30, 1432 argues that it is better to permit the market mechanism to provide these services when required and not permit encouragement of them by restraints. 
services are therefore suspect when used to restrain distributors who are selling products for which there are no effective interbrand competitors. This problem is even greater when the territorial restraints occur in a context of other restraints, such as exclusive dealing or restrictions on resale to customers only. ${ }^{111}$

To encourage pre-sale services and selling effort, the supplier must protect the distributor who provides them from other distributors reaping the benefits of those services-the so-called "cream skimming" problem. Vertical territorial restraints are one way of providing such protection, and can be used to prevent two kinds of cream skimming. The first involves the high-volume, low-cost customer in the distributor's territory. ${ }^{12}$ The use of territorial restraints here seeks to keep other distributors from coming in and skimming off this particular customer with a lower price, leaving the original distributor with accounts which are more costly to service and hence less profitable. If this happens, the original distributor is quite likely to simply stop providing any pre-sale services, or to cease handling the supplier's products. ${ }^{113}$ A second type of "cream" involves promotional and other pre-sale activities. If the original distributor provides such services and thereby attracts a buyer, and another distributor having lower costs and providing less service is permitted to come in and take away the buyer, the original distributor loses the value of the services which he provided. If some protection is not given to this original distributor, he will eventually cease providing the pre-sale services. ${ }^{114}$ Thus, if a product requires pre-sale selling services and distributor effort, some method of preventing cream skimming must be found to encourage those services. Prevention of this cream skimming means that the high profit accounts (those with a high volume and low services cost per unit) are paying for the services to low

Such a mechanism would require that people be charged separately for pre-sale services as they were received. As Professor Posner points out, this may not be feasible with pre-sale serviceshe uses the example of an admission charge for an automobile showroom. Posner 284-85. Of course, the continued existence of high service specialized retailers, such as appliance stores, in the face of competition from low service mass merchandisers indicates that in some circumstances the public is willing to purchase these services at a higher price.

111. DIRLAM \& KAHN 200 concerning exclusive dealing; Jordan 123-24 concerning resale to customers only.

Professor Bork has argued that territorial restraints should be permitted to ensure provision of retail services to all potential customers in the market, even to those customers in markets which are so small that they will not support more than one distributor. Bork II 438-39. When this presumably rare problem is shown to exist, the better solution is to let the parties compete and come to realize their predicament through the competitive realities, resulting eventually in one distributor abandoning the area.

112. Harvard Note 811 .

113. Stone 302 notes that in this situation, a multi-product distributor will promote goods with less intrabrand competition because he does not need to be concerned about the customer getting a better deal elsewhere. See generally Handler 165-66; Zimmerman 1182-83.

114. Bork II 430-31; Jordan 124. The two kinds of cream skimming may both be present in the same sale or sales to one customer. 
profit accounts (those accounts with relatively low volume and relatively higher services cost per unit). Of course, effective price discrimination, if permissible and feasible, would be another way of ensuring services for the relatively low profit accounts, but at a higher price. ${ }^{115}$

The need to prevent cream skimming, however, does not necessarily justify the use of territorial restraints. On large items, it should be feasible to use profit pass-over clauses which pay to the original distributor the cost of the selling services which he provided. ${ }^{116}$ For relatively smaller iteins where customer inobility is not jikely to be as great, areas of primary responsibility restrictions are a possible solution. Although there are some potential probleuns with the use of such restrictions, they do permit a greater local sales effort. ${ }^{117}$ While neither of these alternatives is an ideal solution, each seems to present a workable alternative to vertical restraints when used to prevent cream skimming.

The provision of pre-sale services and distributor effort is more important to a firm new to the market, or an old firm introducing a new product, than to an established firm selling a product which has proved successful. It has been recognized that "[i]n these instances, getting to the market may be the most important problem, and channel development, rather than product developinent, may be the greatest obstacle to penetration of a new market."118 The need for special rules to permit territorial restraints by newcomers and firms introducing new products has been general-

115. Generally speaking, to the extent that price discrimination is cost justified it is permissible. See generally A.B.A. ANTrTRust Section, ANTITRUST Law DevelopmENTS 136-40 (1975). The problem with this defense is proving cost justification in a particular sale even when it is generally conceded to exist. As a practical matter, customer goodwill may not permit granting of even cost justified price discrimination.

116. Profit pass-over clauses have generally been held to be legal where not unreasonable. See, e.g., Superior Bedding Co. v. Serta Assoc., 353 F. Supp. 1143, 1150-51 (N.D. Ill. 1972). It is here assumed that, with large items, the customers and potential customers will consider themselves sufficiently mobile that they will shop in the territory of more than one distributor for the lowest possible price. However, the profit pass-over clause reimburses the original distributor for his promotional expense. Similarly, with larger items there are presumably fewer sales and, consequently, fewer administrative problems in effectively applying profit pass-over clauses and policing sales.

117. Bork II 467-69. Such provisions have generally been held legal if reasonable, and were even approved in the final judgment in the Schwinn case. United States v. Arnold Schwinn \& Co., 291 F. Supp. 564, 565-66 (N.D. Il1. 1968). One difficulty at present, if these provisions are to be used, is that they require the manufacturer to estimate local optimum sales territories and provide for them. Also, as the court indicated in Snap-On Tools Corp. v. FTC, 321 F.2d 825, 832 (7th Cir. 1963), such clauses can be ambiguous, promoting friction and misunderstanding. The Sylvania opinion ended separate treatment for territorial restraints and location clauses. Presumably most pass-over clauses will also be so trcated. See Handler, Recent Antitrust Developments-1965, 40 N.Y.U.L. REv. 823, 848 (1965). For a discussion of the problems which result from requiring a supplier to use the least restrictive alternative, see text accompanying note 144 infra.

118. BELL 698 (emphasis in original). 
ly acknowledged. ${ }^{119}$ Since entry into a new product line or a new business in the concentrated American economy is difficult, a new entrant must be given more powerful market penetrating tools to achieve a position in which it can survive. Where the new product is a high technology one, or one which otherwise requires a great deal of technical skill or pre-selling services to achieve any degree of consumer acceptance, the justification is more compelling. Where the industry structure is oligopolistic, there is an even greater need for new entry to spark price competition and, consequently, the newcomer or new product exceptions would become even more necessary. ${ }^{120}$ It has also been argued that similar treatment should be accorded a failing company. This seems justified, however, only where a highly concentrated industry structure demands retention of existing entities, even in the face of their inability to survive competitively, and the justification should be accepted only for a limited period to permit the failing company to get back on its feet. ${ }^{121}$ To permit the justification indefinitely would be to prop up a company which cannot otherwise survive by the market principles of a competitive economy.

The newcomer and new product justifications should be permitted primarily to attract the distributors necessary to effectively reach the consuming market. This justification becomes less compelling after the new distributors have been able to recoup their initial investments, receive compensation for their initial risks and attain some sales stability. ${ }^{122}$ The same reasoning would justify the use of exclusive dealing arrangements by newcomers or those selling new products. ${ }^{123}$ Because the potential anticompetitive effect of such arrangements is greater than that of territorial restraints, however, exclusive dealing arrangements should be more strictly supervised. Finally, the new product justification should be tempered by the competitive advantages which an already successful firm may have in such a situation. Such a firm would already be in on the ground floor and should, consequently, be better able to capitalize on whatever market demand is available. ${ }^{124}$ This potentially larger payoff, at least in the short run, should be evaluated in determining the need for territorial restraints with a new product.

119. See, e.g., SYMPOSIUM 30-31; THOMPSON 115-17; Baker 541, 546 (using this as a defense to his presumption of illegality); Pogue, supra note 17, at 288-89. This exception was explicitly recognized in United States v. White Motor Co., 372 U.S. 253, 263-64 (1963) and appears to have been sanctioned in Schwinn. Even authors favoring a per se rule have been inclined to make an exception for new products or newcomers. See, e.g., Comanor 1437-38; Stone 316-17.

120. THOMPSON 115-17.

121. Id. 117-18; Stone 316-17.

122. THOMPSON 107-08.

123. Harvard Note 824-26. DiRLAM \& KAHN 184 gives a good example of this reasoning and its effect in the oil industry.

124. Zimmerman 1186. 
Increased pre-sale services induced by vertical territorial restraints may have anticompetitive consequences, as well as the possible procompetitive results discussed above. These anticompetitive consequences are most likely to occur when the territorial restraints exist in the context of one or more of three different fact situations: extensive product differentiation, lack of effective interbrand competition and use of the restraint in combination with an exclusive dealing arrangement.

First, the pre-sale services which territorial restraints induce can have anticompetitive consequences in a market of highly differentiated products. Product differentiation itself can, of course, have either positive or negative effects on competition. When the differentiation exists because the product is functionally different, sells for a different price, or for some other reason meets a genuinely different consumer need, the differentiation is considered to be good. While even this differentiation leads to less competition and higher profit, these consequences are offset by the increased product variety, assuming the differentiation is caused by "superior skill, foresight and industry." 125 The anticompetitive consequences most likely occur when the differentiation is an attempt to give the product a distinctive image only; such image differentiation is typically created by advertising and other promotional efforts. ${ }^{126}$ To the extent that territorial restraints protect dealers from intrabrand competition and, consequently, provide some protection for dealer markups, they may support and encourage excessive advertising expense and services necessary for anticompetitive differentiation. ${ }^{127}$ While the distributor can differentiate on the basis of pre-sale services, which is more socially useful and less anticompetitive, he will more likely use the increased revenues to accomplish or assist in pure image differentiation. However accomplished, any differentiation is a source of market power for the distributor because it protects him from interbrand competition. ${ }^{128}$ Indeed, where there is effective product differentiation, there is a much greater need for intrabrand competition because it is, at that point, the only effective competition. ${ }^{129}$ Thus, restraints curtailing intrabrand competition must be

125. United States v. Aluminum Co. of America, 148 F.2d 416, 430 (2d Cir. 1945). For a discussion of product differentiation, see ScHERER 324-25. Professor Scherer discusses the ways in which differentiation can be accomplished and some of the general benefits it promotes. Id.

126. Id. 326-29 discusses the benefits which have been alleged for image differentiation. The social costs of image differentiation are discussed at id. 329-32. While Professor Scherer's focus is on the effect of product differentiation on market concentration, he generally concludes that excessive image differentiation, usually based on intensive advertising, can have anticompetitive consequences. Id. 344-45.

127. Comanor 1425-26; Zimmerman 1182-83, 1185-86; Jordan 117-18.

128. According to Professor Thompson: "If there were no product differentiation, then the elimination of intrabrand competition would have only minimal anticompetitive effect. Conversely, a high degree of product differentiation with accompanying inelastic demand might make intrabrand restrictions intolerable from a public policy point of view." THOMPSON 100 .

129. ThOMPSON 99-100; Handler, supra note 117, at 847 n.115; Minnesota Note 861-62. 
viewed more skeptically in that situation. In addition, there is less need to induce pre-sale services by vertical territorial restraints where there is no effective interbrand competition; in those circumstances the supplier does not need to induce increased services in order to compete.

As a general proposition, then, intrabrand competition is more important whenever there is less effective interbrand competition-whether the lack of interbrand competition comes from product differentiation or other sources-because the intrabrand competition in effect becomes the only source of competition. ${ }^{130}$ It should also be noted that effective interbrand competition is less likely where the industry structure is concentrated at the manufacturing level. ${ }^{131}$ Product differentiation, as discussed above, is one useful mechanism for transferring this concentrated market structure and its resulting negative effects on price competition from the manufacturing level to the retail level. "If, as is too often the case, the manufacturing segment of the industry is concentrated, the further product differentiation which may be encouraged by the restrictions-the alleged benefit-serves largely to help transfer oligopolistic behavior to the distribution level . . . ."132 Thus, an evaluation of vertical territorial restraints must consider the extent of interbrand competition in determining if any restraint on intrabrand competition should be permitted. ${ }^{133}$ This is true whether the lack of interbrand competition arises from concentration, product differentiation, a combination of these, or any other source.

Finally, the pre-sale services justification for territorial restraints will be much less compelling when those restraints are combined with exclusive dealing arrangements. Generally speaking, the distributor who is subject to territorial restraints and is the supplier's exclusive representative in the territory should not need any further inducement to provide satisfactory selling services. ${ }^{134}$ Such a distributor will either put forth the requisite selling effort or will lose sales. In such a situation, the multi-product distributor will attempt to sell the product which is most advantageous to him-either because the product is easy to sell through its substantial market power, or because the product pays him a greater margin. In either case, the supplier is competing for the distributor's favor by offering a better price or

130. Minnesota Note 857-60 discusses this idea through an analogy to price fixing rules. See text accompanying notes 107-11 supra for a discussion of the impact of a lack of interbrand competition on consumer welfare where vertical territorial restraints are used.

131. See text accompanying notes $182-230$ infra.

132. Zimmerman 1185.

133. Preston 521 states that one factor to be considered in his analysis is "the number and strength of alternative suppliers in intermediate and final markets." But see THOMPSON 114.

134. Harvard Note 796-97. But see DirlaM \& KAHN 198. The business reasons for using exclusive dealing arrangements are discussed in Harvard Note 805-09. Such restraints are usually held to be legal if reasonable. See generally Jordan 131-39 and Sadd, supra note 23, at 249 n. 4 for a review of the case law in this area. 
other terms to the distributor. The exclusive dealing arrangement removes this incentive for suppliers to compete for distributor favor and ties the distributor much more closely to the supplier. Such an exclusive dealing arrangement therefore can be viewed as a nonproprietary form of vertical integration. ${ }^{135}$ Nevertheless, a supplier does need protection against distributors with a philosophy and customer loyalties different from his. Such a distributor may not pursue maximum sales of the supplier's product. ${ }^{136}$ The manufacturer can protect himself in his initial selection process, however, by choosing distributors who have sales and price goals consistent with his. Beyond this, the supplier should not be able to foreclose the competition between himself and other suppliers for the favor of the distributor, for to do so is to restrain one kind of interbrand competition. ${ }^{137}$ This competition among manufacturers for distributors will exist when the distributor sells a number of competing products, or where he can easily switch from one manufacturer to another-in the absence of an exclusive dealing arrangement. Exclusive dealing arrangements also have the potential to foreclose entry into the market at either manufacturing or distribution levels. ${ }^{138}$ Thus, the presumption of antitrust law must operate agamst exclusive dealing arrangements unless some special need is shown. ${ }^{139}$ It is possible that such a need could be shown by facts which demonstrate that a product requires such extensive pre-sale services to attain sales that the distributor can sell only one product. ${ }^{140}$ Without such a showing of extraordinary need, however, the exclusive dealing arrangement should not be justified by the need for pre-sale services alone.

One must also consider whether the provision of these pre-sale services can be achieved by an alternative arrangement which is less restrictive than an absolute territorial restraint. Location clauses can prevent cream skimming on small items because consumers will simply not shop as far away from home. Similarly, profit pass-over clauses can prevent cream skimming

135. Dirlam \& KaHN 173.

136. DALRYMPLE \& PARSONS 416 discusses the different economic goals of distributors and suppliers. ENIS 459 discusses different customer loyalties.

137. Bork II $402-03$ argues that this does not restrain interbrand competition because these restraints cannot add to the market power of the supplier. This view overlooks the potential for entry barriers and foreclosure which can result from these restraints, as discussed below.

Treating this as a foreclosure problem, under $\S 3$ of the Clayton Act, 15 U.S.C. $\$ 14$ (1970), has also been advocated. Preston 520-21.

138. See text accompanying notes $182-204$ infra.

139. DIRLAM \& KAHN 184. This is essentially the conclusion reached by Senator Hart during the hearings on franchising. He noted that exclusive dealing arrangements can foreclose competitor access to distribution, and concluded: "[I]t is also clear that whether engaged in by a large or small, independent or integrated franchiser, an exclusive territorial arrangement with the added ingredient of an exclusive sales or resale price maintenance agreement makes no sense either for a competitive market place or the consumer." Distribution Problems Affecting Small Business, supra note 80, at 697.

140. See DiRlam \& KaHN 184 which discusses the case of the new entrant. 
on large items, for which the clauses are easier to administer, and can help to induce provision of needed services. ${ }^{141}$ With smaller items and items of which more numerous sales are made, it becomes increasingly difficult to administer profit pass-over clauses because the marginal value of pre-sale services on each item sold is difficult to determine and less information on the location of the purchaser is likely to be available for enforcement. While less effective than absolute territorial restrictions, area of primary responsibility clauses can achieve some local sales effort. ${ }^{142}$ Also, in initial distributor selection, the supplier can ensure a dealer philosophy concerning volume and price consistent with his own; ${ }^{143}$ however, the supplier cannot through dealer selection provide the economic motivation necessary to ensure provision of such services. The real problem, however, with a requirement that a supplier use the least restrictive alternative is that it forces him to establish and maintain a distribution system at his peril. ${ }^{144}$ Specifically, the supplier must be able to correctly assess what distribution system a court will later determine to have been the alternative which will meet his needs with the least restraint. This seems an overly harsh requirement to place on the supplier, because in order to operate he must set up a distribution system and at the same time achieve some level of pre-sale services. If the supplier requires or induces a level of services greater than the consumer requires, the market mechanism will bid out those services where there is effective interbrand competition. Thus, there seems to be less need for a requirement that the least restrictive alternative be used in this situation, particularly in view of the lesser degree of effectiveness of those alternatives. Where there is a lack of effective interbrand competition, territorial restraints are a more suspect means of providing pre-sale services.

In conclusion, there are several circumstances in which territorial restraints designed to induce pre-sale services are necessary to encourage competition. First, where there is a newcomer or new product there is a need for greater services and less likelihood that these will be provided. Similarly, the type of product may require a greater sales effort. However, the

141. It has been reported that profit pass-over clauses are the enforcement mechanism most frequently used to enforce territorial restraints. Harvard Note 827; Distribution Problems Affecting Small Business, supra note 80, at 1-493 (Part I). However, this finding is somewhat questionable in light of the voluminous complaints concerning the $\boldsymbol{S} c h w i n n$ decision, which did not prohibit profit pass-over clauses but only prohibited an absolute restraint. It has been reported that in White Motor Co. the enforcement mechanism was $\$ 100$ profit pass-over on a gross margin of $\$ 900-\$ 1000$. Stone 286 n.2.

142. Bork II 467-69. Professor Bork does note that such clauses, to be effective, require the manufacturer to estimate the optimum amount of local sales effort and force it on an unwilling distributor. However, this calculation is being made indirectly whenever vertical territorial restraints are used to induce pre-sale services.

143. Zimmerman 1184-85.

144. Handler 167-68. 
parties seeking to uphold the restraints on this basis should be required to demonstrate that the product requires an extraordinary sales effort which can be induced in no other way. Second, where substantial interbrand competition exists, there is less need to preserve intrabrand competition and a greater need for interbrand market penetration. There is also less of a problem with provision of excess services and less need for concern with least restrictive alternatives. Further, where products are undifferentiated there is less need for intrabrand competition because interbrand competition is more likely. This interbrand competition will therefore discourage excessive image differentiation because the market mechanism should bid it out. Finally, with a product requiring substantial pre-sales effort, it is essential that some method be found to prevent creanı skimming in order to induce provision of those services. In addition, the likelihood of cream skimming is much greater where there is substantial intrabrand competition. Of course, it may be possible to meet this need through location clauses or profit passover clauses, but it may not be satisfactory to require a manufacturer to determine what alternative is least restrictive at his peril.

Several factors correlate with situations where territorial restraints are more likely to be anticompetitive or are most likely to restrict interbrand competition. First, where there is little or no interbrand competition, there is a much greater need for the effects of intrabrand competition and, consequently, any restraint on that competition is seriously suspect. In addition, there is less need for promoting pre-sale services as a way of achieving market penetration. Also, the market mechanism will not bid out excess services, including excessive image differentiation. Second, where products are highly differentiated, particularly through image, vertical territorial restraints will tend to induce the kind of pre-sale services which cause additional differentiation and discourage effective interbrand competition. Third, exclusive dealing arrangements have the effect of reducing competition for the business of distributors and thereby insulate the manufacturer from this kind of interbrand competition. ${ }^{145}$ Moreover, these arrangements are generally unnecessary, as the manufacturer should receive all requisite selling effort from the vertical territorial arrangement alone. Finally, where the product is the kind which requires little sales effort, the effort induced by vertical restraints is much more likely to be image differentiation only. There is also much less of a creain skimming problem with such a product because little pre-sale effort is required.

145. Professor Bork disagrees that vertical territorial restraints can have any output limiting, and hence anticompetitive, effect. See generally Bork II. Thus, it would be argued, exclusive dealing arrangements can never reduce interbrand competition. See text accompanying notes 182-230 infra for a discussion disagreeing with this conclusion. 


\section{B. Promotion of Post-sale Services. ${ }^{146}$}

The underlying policy question in evaluating the justifications for vertical territorial restraints is whether the restraints on intrabrand competition promote interbrand competition, thereby generating a procoinpetitive or at least competitively neutral effect. ${ }^{147}$ This section will evaluate the claim that vertical territorial restraints encourage the provision of post-sale services, such as warranty and maintenance facilities, repairmen and inventories, thereby promoting interbrand competition. To provide post-sale services, the distributor inust inake an investınent in repair facilities, equipment, personnel and inventory. It seems to be generally accepted that this investınent can be induced by increasing the total margin, or gross profit, of the distributor through territorial restraints. ${ }^{148}$ The increased margins are then available to finance the required investment. Thus, one reason for employing vertical territorial restraints is to induce distributors to provide post-sale services.

To evaluate whether provision of such services justifies the restraints, the need of the product for these services must first be determined. ${ }^{149}$ Typically, new products require post-sale services and regular maintenance because no independent provider of maintenance exists. For example, the manufacturer of automatic washing machines may have to supply maintenance and serviee capability with its new automatic washing machines in order to gain customer acceptance. ${ }^{150}$ However, it is much less likely that this justification would be accepted today when substantial independent repair facilities exist. A product with fewer mechanical parts or involving a lower level of technology would have less need for elaborate post-sale service capability. It should be noted that this determination is much more difficult than the similar one involving the need for pre-sale services. All products need some pre-sale services to reach the consuming public; the question is to decide how inuch is needed. However, not all products require post-sale service. Clearly, if the court finds that the product does not require post-sale services, or that the services required are generally available at a

146. The discussion in this section will treat the post-sale services justification as an addition to the pre-sale services justification and will focus on differences between the two.

147. See authorities cited in notes 92-99 supra.

148. Jordan 119-20; Harvard Note 811. Exclusive dealing arrangements also have this effect. Indiana Note 789-90.

149. See BELL 694. Of course, specialized needs of particular customers must also be satisfied; these are considered to be product needs for the purposes of this Article.

150. This example is explained in detail in Jordan 119-20. Another good example of such a product is computer software, where post-sale services of the manufacturer are necessary in order to successfully implement a computer system. This same reasoning was accepted by the court in United States v. Jerrold Electronics Corp., 187 F. Supp. 545 (E.D. Pa. 1960), aff'd per curiam, 365 U.S. 567 (1961), where the court made an exception to its per se rule against tying arrangements for cable television systems, since the industry was in its infancy and the manufacturer was a conpany not diversified in other fields. 
high quality and reasonable price, this justification for territorial restraints would be much less compelling.

Where there is substantial interbrand competition, the existence of a distributorship organization which provides post-sale services may be an important aspect of the overall competitive plan of individual suppliers. Such additional post-sale services can be characterized as a form of product differentiation, under the assumption that a product with repair service available is different than a product without. ${ }^{151}$ Where interbrand competition exists, such differentiation should be permitted because it affords the consuiner a real alternative choice. ${ }^{152}$ With less well accepted products, such post-sale services will increase consumer acceptance and boost sales. The need to provide such services, if part of a competitive plan, may be a partial justification for restraints prohibiting intermediary distributors from selling to outlets which do not provide such services. ${ }^{153}$ However, where there is relatively less interbrand competition, there is less need to impose territorial restraints as a means of securing post-sales services. Here, the post-sales services are not used as a means of competing because there is no effective competition. In this situation the justification should be accepted only with a new product or in a specialized situation in which the product requires unusual post-sale services which cannot be secured any other way. ${ }^{154}$ Here again, the general policy in favor of intrabrand competition where there is little interbrand competition may override the need for postsale services.

When these restraints are used in a market with little interbrand competition, some mechanism is needed to ensure that consumers are not sold more services than they wish. Where there is effective interbrand competition, the operation of the market will bid out the provision of excess services to the extent that the services raise the price. ${ }^{155}$ Where there is no interbrand competition, however, there is no external limit on provision of more services than the consumer wants. ${ }^{156}$ This, then, is an additional reason to limit or prohibit the use of vertical territorial restraints to achieve post-sale services.

The need to use vertical territorial restraints to induce post-sale services can be even greater in dealing with a new product, or a new entrant into an existing product market, where the product's characteristics require that

151. SCHERER 324 cites quality of service as one method of differentiating the product.

152. THOMPSON 99-100. See generally Minnesota Note 861-62.

153. Zimmerman 1185 notes that many suppliers wish to keep their products from being sold in discount houses partly because satisfactory post-sale services are frequently not available.

154. Baker 546 recognizes the complex product justification as a defense to his proposed rule of presumptive illegality. A similar justification was accepted in United States v. Jerrold Electronics, 187 F. Supp. 545 (E.D. Pa. 1960), aff'd per curiam, 365 U.S. 567 (1961).

155. HESKETT 346-47.

156. See Comanor 1425-26. 
post-sale services be made available. A newcomer or new product will have greater need for these services and less ability to provide them without restraints. With a new product or a new entrant, the consuming public is more likely to demand post-sale services as an assurance of the quality of the product. In addition, it will be more difficult to find distributors willing or able to make the investment necessary to provide them. Hence these restraints must be used to induce distributor investment. ${ }^{157}$ It is apparent that the use of vertical territorial restraints will give the newcomer or new product a less expensive way to pay for post-sale services, in that they will be financed by increased dealer margins, rather than direct payments from the manufacturer. In the long run the economic incidence of this shift is not significant; in the short run, it may help to alleviate a capital shortage of the newcomer or the business introducing a new product. Of course, this additional justification should be accepted only where and as long as this "head start" is necessary. ${ }^{158}$ If there is a ground floor advantage in the new product, this should be weighed as a partial offset of the added justification $^{159}$ because the potential for higher short run profits will offset the additional risk. Where the product does not require substantial post-sale services, or where they are otherwise available, the newcomer or new product justification would not be applicable.

In order to ensure the provision of post-sale services, it is necessary once again for the manufacturer to solve the problem of a "free ride" or "cream skimming." 160 This problem arises when one distributor makes sales for which he does not provide facilities for adequate post-sale services, or does not provide them in a location convenient to the customer, and another distributor is required to perform these services. Traditionally, performance of post-sale services is not a high profit activity and there is a tendency to cut corners on them if they are not adequately compensated. ${ }^{161}$ The distributor who provides a lower level of services, or no services at all, presumably has a lower operating cost. Thus, he can afford to make sales at a lower price. The net result is that the full service distributor makes fewer sales, because he has a higher price, and has more low profit post-sale services to provide. In such a situation, the full service distributor will not be able to survive without some protection. ${ }^{162}$ Without protection he will be

157. See generally authorities cited in notes 118-24 supra for discussion of the new product and new entrant justifications. On the need for these to induce investment, see Baker 547; Harvard Note 826.

158. Comanor 1437-38. Professor Comanor uses the "head-start" terminology.

159. Zimmerman 1186.

160. See text accompanying notes $112-17$ supra for a discussion of "cream skimming" in the context of pre-sale services.

161. Harvard Note 811-12. See text accompanying notes 169-70 infra for a discussion of whether this problem can be solved by raising the price of the product at the supplier level to provide funds for increased compensation for services at the distributor level.

162. Bork II 446-49; Handler 165-66; Zimmerman 1182. 
forced out of business and the supplier will eventually be represented only by distributors who provide a lower level of service or no service at all. Territorial restraints provide this protection in that they keep one distributor from raiding the territory of another and remove the incentive for this free ride. ${ }^{163}$ As with pre-sale services, a location clause may effectively accomplish this result for smaller or less expensive items, and a profit pass-over clause may effectively accomplish it for larger or more expensive items. ${ }^{164}$

When the need for post-sale services arises in the context of an exclusive dealing arrangement, vertical territorial restraints may be less justified. With an exclusive dealing arrangement, the distributor must be as concerned as the supplier with consumer acceptance of the product. If necessary post-sale services are not available, the consumer will purchase other products and the distributor will not make sales. Unless the distributor is able to change suppliers before this happens, he will be out of business. Thus he needs no further inducement to provide truly necessary services. Of course, the distributor's short run strategy, and the degree of consumer loyalty sought, may be different from that of the supplier and, for this reason, the distributor may be less interested in long term consumer acceptance. ${ }^{165}$ This problem can be substantially remedied, however, with careful distributor selection initially. Therefore, in the context of an exclusive dealing arrangement, the need for post-sale services will generally not justify vertical territorial restraints.

One must consider whether there are other ways to provide these services. It has been argued that where there exists a need for post-sale services, a separate market will develop for the provision of these services, so that inducement through vertical territorial restraints will not be needed. ${ }^{166}$ This argument appears to have more validity in the case of postsale services than pre-sale services, since post-sale services are, presumably, the kinds of services that could be provided by an independent repair facility, or at the supplier's factory, rather than by the distributor. However, because provision of these services is typically not a high profit activity, it is relatively less likely that a satisfactory independent service capability will emerge. If it does emerge, a higher cost should be charged for the services to raise the profit level-although this would presumably be concurrent with a

163. Bork II 446-49.

164. See text accompanying notes 116-17 supra. On small or less expensive items, the consumer will not shop in as wide an area and a location clause will be equivalent to territorial restraints if the locations are dispersed sufficiently. On large or more expensive items, there will be few enough sales and enough purchaser information to administer a profit pass-over clause. The same problem discussed in text accompanying notes 141-44 supra, however, arises here with requiring this least restrictive alternative; the supplier must bear a heavy burden, since a court may not later agree with his choice.

165. See authorities cited in note 86 supra. For authorities dealing with exclusive dealing generally, see notes $134-40$ supra.

166. Comanor 1429-32. 
lower product price because the initial purchase cost would not be supporting provision of services. In any event, it has been persuasively argued that the sale of these services separately will result in incentive to cut corners and provide less satisfactory services. ${ }^{167}$ If services are provided by an independent service capability, the supplier will have very little control over these services, even though they may be essential to consumer acceptance of the product. Furthermore, in many industries with complex products the independent service capability will simply not exist without training and organization efforts by the manufacturers, which can be provided more effectively to selected, identified distributors. The size and other shipping and service characteristics of the product may make direct provision of services by the supplier impractical or inefficient. Finally, it is probably not feasible to induce provision of post-sale services through price reductions by the supplier. Such reductions are usually passed on as lower prices rather than used to finance the desired services. ${ }^{168}$ If this happens, the supplier winds up with a product which is sold for less, but the purchase price of which does not pay for services which he believes are necessary to ensure continued acceptance of the product. Thus, in the absence of an existing, independent post-sale service provider the manufacturer can legitimately claim that some trade restraint is needed to ensure provision of post-sale services.

Even if some trade restraint is necessary, it need not be an absolute territorial restriction. Instead, the supplier could simply require that all his dealers maintain an effective post-sale services capability. Such a requirement will make the supplier's products less desirable, however, and could probably be enforced only by suppliers with a strong market position and hence a strong bargaining position vis-a-vis distributors-precisely the supplier who has less need of these restraints. Thus, the core problem with a rule permitting only this supplier requirement is that it would require a court to determine whether the manufacturer could have attracted distributors without territorial restraints. Those who can attract distributors without territorial restraints would presumably be required to do so. A rule based on such a hypothetical determination does not appear to be workable. One other problem with simply requiring service capability is the quality of the service which will be rendered. Because provision of post-sale services is traditionally a low profit function, distributors will not be interested in supplying the best quality services and will be inclined to cut corners. ${ }^{169}$ Of course, the supplier can raise the compensation for these post-sale services. If the increase is payable by him, he will have to raise the price of his product to support it, placing him at a relative competitive disadvantage. If the increase

167. Bork II 446-49.

168. BELL 713-14.

169. Bork II 446-49; Harvard Note 811-12. 
is paid directly by the consumer, the product becomes relatively less desirable because of the increased cost of repair services. If suppliers cannot use territorial restraints, they would be required to increase either the cost of the product or the cost of the services which are charged to the consumer. It is then possible that an independent repair service would emerge because it would be adequately compensated. However, the provision of post-sale services, which are necessary for consumer acceptance of the product in question, would be subject to less supplier control.

Another potentially less restrictive alternative is the use of profit passover clauses. On the surface, it appears that such an alternative would be effective as these clauses are the mechanism frequently used to enforce absolute territorial restraints. ${ }^{170}$ To the extent that the manufacturer can accurately compute the per sale cost to the distributor of post-sale services, and the profit pass-over clause can be enforced on every sale, this is a realistic alternative. This appears to be more feasible, however, in dealing with relatively larger or more expensive products, since such computation and policing will surely entail additional cost. The relevant calculation for a court would be one comparing the cost of the profit pass-over clause to the increased price, if any, which would result from decreased intrabrand competition if vertical territorial restraints had instead been used. Thus, if it could be established that these clauses did in fact entail less cost, then they should be permitted. Unfortunately, until this has been established, it is simply not possible to evaluate whether this less restrictive alternative is desirable. One must also be skeptical that the clause can be enforced or policed with one hundred percent effectiveness, and any less effectiveness will tend to deter the provision of post-sale services. As discussed above, location clauses can be used to discourage cream skimming in the sale of small or less expensive items for which consumers will not shop in as wide an area. However, when so used, the location clause has much the same effect as the absolute territorial restraint and is, for this reason, no more preferable. ${ }^{171}$ The use of area of primary responsibility clauses would also be unsatisfactory, since such clauses do not encourage post-sale services. ${ }^{172}$

In sum, a simple requirement by manufacturers that dealers provide post-sale services meets some of the need for provision of those services,

170. Stone $286 \& \mathrm{n} .2$, which discusses the $\$ 100$ profit pass-over provision in the White Motor Co. case; Harvard Note 814-16. See note 116 supra and accompanying text for a discussion of the mechanics of profit pass-over clauses.

171. SYMposium 60-63 ascertains when location clauses can have the same effects as absolute territorial restraints.

172. Bork II 467-69 discusses why area of primary responsibility clauses do not encourage post-sale services. Basically, the problem is that such ciauses only encourage intensive coverage of a particular area, allowing the distributor to sell in other areas also. Thus, there is no elimination of intrabrand competition and no increase in distributor profits. Handler, supra note 117 , at 848 discusses the problems caused by the ambiguity and misunderstanding engendered by these clauses. 
but is less satisfactory than a territorial restraint. A profit pass-over clause, where it can be administered, has the potential to be a less restrictive alternative. However, it may be less effective in encouraging the servicesit only keeps from discouraging them-and may entail more costs than the territorial restraint. Of course, a court should examine whether the combination of these two requirements would, in an individual case, accomplish the same result as a territorial restraint. As in the case of pre-sale services, there is a fundamental problem with requiring a supplier to use a method of inducing needed post-sale services which will later be held least restrictive. ${ }^{173}$ This determination is made after the fact and concerns a business decision which is difficult to change. ${ }^{174}$ Given the questionable effectiveness of these lesser restrictive alternatives, this serious restriction on business decision-making does not appear justified.

In conclusion, a determination of the justifiability of vertical territorial restraints to induce post-sale services should focus on the following determinations: whether the nature of the product requires substantial warranty or other post-sale services which will probably not be available if not encouraged by the supplier; whether there is substantial interbrand competition, because if so, it is unlikely that the service being sold is more than the consumer wishes, or is more than is necessary to gain consumer acceptance and compete effectively; whether the product being distributed is a new one, or if the supplier is a new entrant into the industry, indicating that the restraints will likely be more justified to encourage provision of post-sale services which will probably be more necessary; whether there is substantial industry concentration, since it is even more desirable to encourage a new entry to spark competition, further justifying the restraint; whether exclusive dealing arrangements are used, where a distributor does not need the inducement of territorial restraints to achieve necessary post-sale services; and finally, whether less restrictive alternatives, such as separate sales of post-sale services, compensated at a higher rate, or profit pass-over clauses, may be available. The court, however, would have to evaluate the facts in each situation to determine whether the alternative meets the manufacturer's legitimate needs, and there exists serious question whether such a hypothetical determination is feasible or proper for a court.

173. See Handler 167-68.

174. See id. Preston 511,518 concludes that these restraints can increase the number of outlets by their restriction of intrabrand competition. But see THOMPSON 110-14 for a discussion of the problems with Preston's theoretical model. Sandura Co. v. FTC, 339 F.2d 847 (6th Cir. 1964), is frequently cited as a good example of the need to use restraints to encourage preferential selling effort from multi-product distributors so that the supplier can stay in business.

Stone $310-11$ points out that these restraints can also encourage loyalty by avoiding duplicating selling effort. Typically our system prefers to allocate this kind of activity through the competitive effects of the market mechanism rather than by planning. 


\section{Encouragement of Distributor Loyalty.}

Vertical territorial restraints are frequently justified as a means of encouraging distributor loyalty. As used here, loyalty is more than simple encouragement of pre-sale or post-sale distribution services. The loyalty sought to be induced is one or both of two dealer responses. First, loyalty can take the form of preferential pre-sale services from the multi-product distributor. Such loyalty results in the distributor pushing sales of one supplier's products over those of another for reasons other than the quality of the products or their suitability to the purchaser's needs. Secondly, distributor loyalty can be a refusal of the distributor to sell new, additional product lines or, at the very least, a refusal to cease selling a given supplier's line in the face of competitive pressures. This response achieves some stability in manufacturing and distribution operations, but can also have anticompetitive consequences. These two kinds of distributor responses will be discussed separately and the validity of loyalty as a justification will be evaluated in light of its effect on competition.

Territorial restraints can encourage preferential pre-sale services from the multi-product distributor because they restrain intrabrand competition and consequently reduce the likelihood that the distributor will engage in pre-sale selling services only to have the sale taken away by his intrabrand competitor. ${ }^{175}$ As previously discussed, vertical territorial restraints do provide protection from intrabrand competition. ${ }^{176}$ This protection can induce the distributor to favor one product over another because he knows that he and not an intrabrand competitor will receive the sale. If the market position of a second product is sufficiently strong, however, it can overcome this advantage. To permit restraints to encourage these services is to permit manufacturers to compete for the favor of distributors, not on the merits or price of the products, but on the "bribe" paid to the distributor. ${ }^{177}$ Howev$\mathrm{er}$, if meaningful interbrand competition exists at the retail level, there will not be serious anticompetitive effects from this pre-sale preference. A distributor who is preferring a product which cannot successfully compete otherwise will lose sales to his interbrand competitor. Eventually, the distributor will stop granting the preference if it is costing him sales because a low profit sale on an unpreferred product is better than no sale at all on a preferred product. Thus, meaningful interbrand competition will bid away the anticompetitive effects of the preferred pre-sale effort.

The second kind of loyalty response to vertical territorial restraints is the tendency to continue to sell the supplier's products, even when they are not the best competitive alternative. This kind of distributor loyalty achieves

175. See authorities cited in note 174 supra.

176. See authorities cited in note 92 supra.

177. Comanor 1436 discusses why non-price competition should not be encouraged. 
stable sales and resulting efficiencies at the manufacturing and distribution level. ${ }^{178}$ This orderly marketing does create firm level efficiencies which should be encouraged, particularly in industries with high fixed costs or histories of extremely unstable markets. In those situations there is an extraordinary need to achieve some stability and this kind of dealer loyalty is one way to do so. In some circumstances, however, orderly marketing can be achieved by less restrictive alternatives, such as careful dealer selection and area of primary responsibility clauses. ${ }^{179}$ The needs of a particular industry for stable markets must be evaluated in each case to determine how great those needs are and whether they can be met by less restrictive alternatives. But where there are great needs and the alternatives would not meet them, vertical territorial restraints would be justified. In any event, where there is effective interbrand competition, this stability-seeking dealer loyalty is not likely to have anticompetitive consequences. As with the preferential pre-sale services discussed above, the market mechanism will bid out excessive stability where there is interbrand competition. Where such interbrand competition does not exist, excessive dealer loyalty to promote stable sales by too many manufacturers and distributors may foreclose a newcomer or new product or may aid a highly concentrated manufacturing industry in achieving interdependent pricing. ${ }^{180}$

As has been true with pre-sale services and post-sale services, a newcomer or a new product in the market may have a greater need for distributor loyalty. ${ }^{181}$ In such a situation preferential point-of-sales services may be essential to break into the market and achieve sufficient consumer acceptance to survive. Similarly, there is a greater need for stability on the part of a new manufacturer or manufacturer of a new product. Thus, vertical

178. Bork II 429; Zimmerman 1184; Columbia Note 514. KAYSEN \& TURNER 120-22 discusses these efficiencies in the context of vertical integration rather than vertical restraints.

It is argued that there are "new" economic reasons for vertical integration. The combination of imperfect information, also known as "bounded rationality," enforcement costs of contracts governing vertical relationships, and an unequal distribution chain, all encourage vertical integration because integration reduces the risks from these problems and reduces the cost of responding to them by internalizing them, permitting the establishment of system goals and operation by fiat. See Phillips $575-76$ and authorities cited therein. It appears that vertical restrictions would permit the reduction of risks, and the cost of responding to risks which arise from imperfect information and unequal distribution of information. These goals could also be accomplished by at least partially internalizing these problems, although this solution is less complete than vertical integration.

179. Thompson 106-07, 108-10; Stone 308-09; Zimmerman 1184. Stone also comments that the type of product may lock in the distributor to the supplier to such an extent that restraints are not necessary-using White Motor $\mathrm{Co}$. as an example.

The same difficulty exists with requiring the least restrictive alternative here as in the presale and post-sale services problems. See notes 143-44 supra.

180. See text accompanying notes 182-230 infra for discussion of the entry-barring and oligopolistic interdependence facilitating potential resulting from vertical territorial restraints.

181. For example, see BELL 698-99 concerning strategy and its relative importance; SYMPOSIUM 30; Posner 293. 
territorial restraints to induce distributor loyalty are more justified when used by a newcomer or an existing manufacturer introducing a new product.

Where substantial product differentiation exists there is less need for restraints to induce distributor loyalty. Such differentiation protects distributor margins by decreasing interbrand competition. This protection should therefore be sufficient to ensure distributor loyalty. A similar situation exists when exclusive dealing restraints are used. A distributor bound exclusively to one supplier will wish to promote sales to avoid having to change suppliers and lose whatever customer goodwill the supplier's product has achieved. Such a distributor has no occasion to render preferential pre-sale services because he sells only one product. The success of a distributor selling only the products of one supplier is directly related to the achievable sales of that supplier's product. Thus there is no need for territorial restraints to achieve additional loyalty.

An evaluation of the justification of restraints arising from the need for distributor loyalty should therefore focus on several factors. First of all, if there is substantial interbrand competition, loyalty derived from preferential pre-sale services and stability will not have substantial anticompetitive consequences because those consequences will be bid out by the market mechanism. Also, where it can be established that a particular manufacturer or a particular industry has unusual needs for sales stability, or an unusual history of instability in the past, there may be an even greater justification for restraints. In addition, a newcomer or new product has greater need for distributor loyalty and less possibility of securing it without restraints. In a situation where there is substantial product differentiation there is less need for loyalty induced by territorial restraints. Finally, if exclusive dealing arrangements are used, pre-sale preference is not an issue and loyalty to achieve stability should be present already.

\section{Creation of Entry Barriers.}

It is the thesis of this section that vertical territorial restraints (and exclusive dealing restraints) can create market power or otherwise cause barriers to entry which would not result from market power at the horizontal level alone. Substantial disagreement exists concerning this thesis. It has been argued that manufacturers restrict distribution for only two reasons: to enforce a dealer cartel which is actually a horizontal agreement and to ensure point-of-sales services. ${ }^{182}$ However, this conclusion overlooks the fact that entry barriers can be created or strengthened by territorial restraints, and also that these restraints can facilitate interdependent pricing in an oligopolistic industry structure. ${ }^{183}$ It has also been argued that vertical

182. Posner 283-85.

183. See text accompanying notes $205-30$ infra. 
market division can never add to horizontal market power and, for this reason, can never create more anticompetitive effects than could be achieved through the exercise of horizontal market power alone. ${ }^{184}$ This position has been disputed by others in the area. ${ }^{185}$ If the supplier can achieve effective foreclosure, increased capital requirements for others, and effective product differentiation, he can impose disproportionately high

184. According to Professor Bork:

A vertical elimination of competition by a single manufacturer can, by definition, never affect a larger proportion of the total output of the industry than the manufacturer produces. This means that the elimination of competition at the retail level creates no more market power than the manufacturer has at the manufacturing level. Vertical price fixing and market division, therefore, creates [sic] no additional horizontal market control and hence raise no danger of additional power to restrict output .... Only one full monopoly return can be taken from a series of vertically related activities.

Bork II 402-03. See also id. 415-16. The same argument is made concerning vertical integration in Bork, Vertical Integration and the Sherman Act: The Legal History of an Economic Misconception, 22 U. ChI. L. Rev. 157, $195-97$ (1954). Contra Kaysen \& TuRNER 120-22; Blake \& Jones, In Defense of Antitrust, 65 Colum. L. REv. 377, 392-93 (1965). For a view supporting that of Professor Bork, see Preston 520. But see THOMPSON 114 for criticism of Preston's model. Allen, Vertical Integration and Market Foreclosure: The Case of Cement and Concrete, 14 J. LAw \& ECON. 251, 270-72 (1971) concludes that what limited evidence there is suggests that foreclosure and entry-barring resulting from these kinds of restraints have not been profitable strategies even when they have been deliberately pursued. This first conclusion is disputed in Meehan, Vertical Foreclosure in the Cement Industry: A Comment, 15 J. LAw \& ECON. 461, 462-65 (1972), arguing essentially that Mr. Allen assumes away the effects of foreclosure and has not demonstrated that it is in fact unprofitable. But see Allen, Vertical Foreclosure in the Cement Industry: A Reply, 15 J. LAW \& EcoN. 467 (1972).

Professors Bork and Bowman have argued that any theory of the anticompetitive effects of exclusionary practices is unproved. Bork \& Bowman, The Crisis in Antitrust, 65 Colum. L. REV. 363, 366-68 (1965). They go on to contend that these practices are either competitive tactics available to all or simply a means of maximizing market position already held. They argue that the theory of exclusionary practices requires two assumptions. First, with effective foreclosure and the barriers to entry, to be discussed below, it is quite likely that an existing competitor can impose greater costs on new entrants and can probably impose greater costs on his rivals who wish to expand. Second, imperfections in the capital market permit the restricting supplier to offer greater inducement than his rivals. Bork and Bowman, however, argue that no such imperfections are shown. Id. This conclusion is specifically disputed in Blake \& Jones, supra, 392-93 in the case of vertical integration. For a further discussion of Professors Bork and Bowman's argument, see also Bowman, Contrasts in Antitrust Theory, II, 65 COLUM. L. REV. 417 (1965).

While the theory of exclusionary practices has been opposed on a theoretical level as discussed immediately above, there appears to have been little effort to determine what entry barriers or foreclosure may in fact result from these practices.

Professor Carstensen has criticized Professor Bork's approach for considering only static analysis and not dynamic factors. Carstensen 785-88. He argues persuasively that restraints may be used dynamically to create market power as well as statically to exploit power already existing. He also advocates an analysis using, in addition to static equilibrium theory, a dynamic theory which considers "causation and control of growth and change in an economy." Id. 791 \& n.57. He also notes that the difficulty in using such an approach is that there are few rules to test whether change caused by supplier level restraints is desirable. Id. 796. This Article considers the dynamic potential of restraints in this section and in text accompanying notes 205 30 infra, and also attempts to provide guidance in determining when vertical territorial restraints should be permitted, considering both dynamic and static factors.

185. Phillips 575-77. 
costs on his competitors and make entry into effective competition with him at the retail level difficult. This section will discuss how these three barriers to entry can result from vertical restraints. It will conclude with an analysis of when the erection of entry barriers will be encouraged by vertical restraints and an identification of factors which will aid in evaluating the potential for exclusion of particular restraints.

One of the most effective barriers to entry is foreclosure of competitors from access to the market. Clearly, to the extent that a manufacturer can do this he achieves an advantage by making marketing much more difficult for his competitors and potential competitors. It has been argued that foreclosure cannot be achieved by vertical restraints because a potential new entrant can simply offer enough profit to induce the opening of new distributorships to handle his products. ${ }^{186}$ However; the theory of foreclosure operates on the assumption that a competitor can impose on his rivals greater costs than his own. By tying up existing distributors with restraints, a competitor can increase his rivals' costs and achieve foreclosure by forcing them to offer sufficient price incentive to induce new entry into the distributor market, rather than simply luring away existing distributors of his competitors. Because of the greater risk and potential unavailability of capable distributors, ${ }^{187}$ new entry at the distributor level is bound to be more expensive. Thus, it appears that foreclosure is a strategy that is theoretically achievable and profitable. ${ }^{188}$

However, it may still be questioned whether vertical territorial restraints, standing alone, can cause foreclosure. If all manufacturers in a given market can offer these restraints, it would appear that the protection afforded by territorial restraints would simply be one element in the overall competitive scheme among suppliers for the business of distributors. However, these restraints can be used to achieve preferential distributor services and stability in the dealership organization. ${ }^{189}$ Thus imdividual distributors are less accessible to the supplier's competitors and potential competitors

186. Bork \& Bowman, supra note 184, at 366-67. See generally the authorities and discussion in note 184 supra.

187. DALRYMPLE \& PARSONS 403 reports that the unavailability of middlemen of the kind, type and quality which a supplier prefers is a very real problem in marketing generally. Clearly this difficulty would be even greater for the new entrant.

188. Baker 541-42; Phillips 576-77. See discussion in note 184 supra concerning the study done of the profitability and use of foreclosure as a strategy in the concrete and cement industry as discussed in Allen, Vertical Integration and Market Foreclosure: The Case of Cement and Concrete, supra note 184, at 270 and Meehan, supra note 184, at 465.

See generally Jordan 130-31, where a desire to drive out competitors by making their marketing more difficult is discussed as one purpose of these restraints. See also Minnesota Note 860 , where the author recommends using foreclosure of competitors as one test in evaluating these restraints, as was proposed by the 1955 Attorney General's study. REPORT OF THE AtToRney GenERAL's National Commitee to Study the ANTITRUST Laws 27-29 (1955).

189. See text accompanying notes 67-82 supra. 
because they are harder to bid away. If used by all suppliers, these restraints may contribute to a static situation in which new entry or market expansion by existing entities is virtually impossible because distribution is foreclosed, particularly where there is substantial market power at the supplier or distributor level. ${ }^{190}$ Thus, there is at least a potential for foreclosure in vertical territorial restraints sufficient to require the court to determine if there is in fact foreclosure in a particular case.

The potential for achieving foreclosure by vertical restraints is increased when territorial restrictions are combined with exclusive dealing arrangements. ${ }^{191}$ Such an arrangement of course restricts the distributor to the product or products of one supplier. To the extent that the product itself develops consumer acceptance, such an exclusive dealing arrangement will make it more difficult for the distributor to change manufacturers should he so desire. ${ }^{192}$ The fact that the distributor must make a total shift in the product line he handles to switch manufacturers, rather than simply adding another product to his line, makes the consequences of such a shift more unpredictable and, accordingly, less likely. Where there is little effective interbrand competition, the additional protection from intrabrand competition is even more likely to provide the greater-than-norinal profit to the distributor, tying him even more closely to the manufacturer. Thus, vertical territorial restraints should be viewed even more cautiously when they are used in combination with exclusive dealing arrangements.

Unfortunately, it is not easy to evaluate the extent to which vertical territorial restraints may accomplish foreclosure in a particular case. The relative ease of entry at the distributor level, the capital requirements for new entry at that level and the existence of effective interbrand competition will all be relevant. The use of territorial restraints and exclusive dealing arrangements together, however, should be suspect absent substantial justification. Where effective interbrand competition exists, there is less to fear from potential foreclosure because there has not been effective foreclosure in the past.

The second barrier to entry which can arise from vertical territorial restraints, that of increased capital requirements, is related to the first. Where there is effective foreclosure, the new entrant, seller of a new product, or expanding firm must enter or expand at the distribution as well

190. Allen, Vertical Integration and Market Foreclosure: The Case of Cement and Concrete, supra note 184, at 271 asserts that foreclosure is a strategy which is pursued in the cement and concrete industry, presumably on the assumption that it is profitable. (Allen goes on to conclude that this strategy is not profitable; see authorities cited in note 184 supra for discussion of this conclusion).

191. Baker 542. DiRLAM \& KAHN 178 gives an example of such foreclosure and concludes that there is some potential for foreclosure even in an exclusive agency arrangement.

192. The present trend toward nationwide branding of products and nationwide advertising increases the possibility that the product itself will develop substantial consumer acceptance. 
as at the manufacturing level. To make the product accessible to the consumer it is necessary to make a new entry at both levels. Such an entry is more difficult because it must be made in the face of two kinds of increased capital requirements.

First, the new entrant must raise more capital than would be necessary for entry at one level. This increased capital requirement discourages new entry or expansion. ${ }^{193}$ It has been argued, however, that a greater quantity of capital required is not a barrier to entry because there has been no proof of higher capital costs and, consequently, no relative disadvantage. ${ }^{194}$ This position rests on the assumption of static economic theory that there is "perfect knowledge and mobility in the capital market and among entrepreneurs." 195 It is generally accepted, however, that an existing, well established company selling in existing, profitable and stable markets will have an easier time obtaining capital at lower costs than a new entrant or an existing firm expanding into new markets. Similarly, capital markets are not perfect and it is easier to raise large amounts of capital for an established venture than a new one.

These imperfections also relate to the second entry-barring result arising from capital requirements. In addition to the greater quantity of capital needed, the capital which must be obtained can be secured only at greater costs. This is true because there is a greater risk involved in multi-level entry and, consequently, a higher price must be paid to induce the capital to participate. ${ }^{196}$ This is particularly true in view of the fact that the competitive position of the distribution system, as a system, can only be as strong as its weakest link. Thus, a new entrant must succeed at all levels of the distribution chain to become an effective competitor. It has been argued that the new entrant or expanding firm would not be required to enter or expand at every level, but could coordinate its entry or expansion with that of another firm, and that potential profits, rather than risks, should be cumulated to determine capital costs from multi-level entry. ${ }^{197}$ This argument fails, however, to consider the interdependence of ineinbers of the distribution system and the need for the system to function effectively as a unit. ${ }^{198}$ Because of this interdependence, there will likely be no profits unless the new entrant or expanding firm functions well at all levels, and the risk of not functioning well is imcreased when separate entities are involved.

193. See authorities cited in Blake \& Jones, supra note 184, at 392 n.55.

194. Bowman, supra note 184 , at 419 argues that there is no relative disadvantage. Bork \& Bowman, supra note 184, at 366-67 argues that costs are no greater than those of rivals. See also Bork, Vertical Integration and the Sherman Act, supra note 184, at 195.

195. Blake \& Jones, supra note 184 , at 393 . They note that there are fewer sources of capital when larger amounts are required. Id. 392-93 \& n.56.

196. Id. 393.

197. Bork, Contrasts in Antitrust Theory, I, 65 CoLum. L. REv. 401, 406-07 (1965).

198. See authorities cited in notes 83-91 supra. 
This increased risk will result in even higher capital costs. Coordinating new entry between or among a number of firms will be difficult and expensive, and accordingly, discouraged.

Where the new entrant or expanding firm is attempting to break into an industry in which vertical restraints of competitors already exert these capital costs barriers to entry, restraints may be justified to permit spreading of the capital cost of this new entry or expansion. ${ }^{199}$ This justification, however, should be permitted only where foreclosure through increased capital costs is proven. Generally speaking, if foreclosure can be accomplished through the use of vertical territorial restraints, increased capital requirements and increased capital costs can be imposed on competitors and both will have a deterrent effect on new entry.

The third possible barrier to entry which can arise from territorial restraints is the creation of product differentiation based on image advertising. Vertical territorial and exclusive dealing arrangements can encourage image differentiation, ${ }^{200}$ which can make the pre-sale, post-sale services and dealer loyalty justifications less compelling. ${ }^{201}$ In addition, this differentiation can have an even greater anticompetitive effect because it can be a meaningful barrier to new entry. The essence of image differentiation is that it creates a degree of consumer acceptance not justified by either the characteristics or the price of the product. This consumer acceptance makes it relatively more difficult for a new entrant or an expanding firm to enter the market. ${ }^{202}$ The new entrant must at least bear the increased advertising and other expenses necessary to combat existing consumer acceptance and create some consumer acceptance of his own. This increased cost can combine with the greater risk of combating established consumer preferences to deter new entry. Therefore all product differentiation, it has been

199. Franchising is one good way of spreading these costs, although franchising will frequently involve vertical restraints. THOMPSON 35 notes that one advantage of becoming a franchisee is low capital costs, because someone else is paying the capital costs. He uses the example of the automobile business franchising arrangements as a way of spreading costs. Id. 19-21. See also Phillips 576.

200. Comanor 1422-25. It is on precisely this point that Professor Comanor disagrees with Professor Bork's statement that there can be no anticompetitive motives for imposing these restraints. Bork II 403 . "These restraints also serve to promote product differentiation and contribute thereby to the achievement of market power." Comanor 1427 n.24. See generally Harvard Note 833 . Zimmerman 1185 notes that this product differentiation is more likely and more anticompetitive in the context of a concentrated manufacturing industry.

201. See text accompanying notes 100-45 supra.

202. According to Professor Scherer:

Intensive advertising can also raise barriers to the entry of new competition, permitting producers to enjoy for extended periods of time monopoly profits commensurate with their power over price. Thus, high prices, waste, income redistribution in favor of stockholders, and misallocation of resources are the consequences of excessive image differentiation.

SCHERER 344. See generally SCHERER 341, discussing cost and preference barriers to entry created by differentiation. 
argued, leads to less competition and higher profits. ${ }^{203}$ Where the differentiation is based on different product functions, physical characteristics, performance or price, the differentiation should be encouraged to enhance product quality and variety and to promote manufacturer rivalry. This is not the case, however, where the differentiation is a function only of advertising and promotional expense and effort. ${ }^{204}$ Thus, it may be necessary to tolerate some degree of entry-barring effect to encourage socially useful product differentiation, but it is not justifiable to tolerate such effect in order to achieve image differentiation only.

In summary, there are three entry barriers which vertical territorial restraints may create or foster: foreclosure, increased capital requirements and product differentiation based on advertising. Foreclosure can result from excessive distributor loyalty induced by the restraints, and when territorial restraints and exclusive dealing arrangements are combined, the potential for foreclosure is much greater. The absolute amount of capital required and the relative cost of that capital are also indications of the strength of entry barriers. Finally, the existence of substantial image differentiation indicates that there is a substantial barrier to entry. Where effective interbrand competition exists, however, it is a good indication that barriers to entry are not a problem. Where entry has been attempted, this experience should be closely examined to determine the results of the attempt and reasons for them. Where there are other barriers to entry it may be necessary to prohibit restraints so as to discourage further barriers unless persuasive justifications are established. Where restraints are used and no new entry is attracted into stable industries earning long-term high profits with the potential for foreclosure discussed here, the entry-barring effects of the restraints should be carefully scrutinized.

\section{E. Facilitation of Manufacturer Oligopoly Interdependence.}

In an industry with an oligopolistic structure at the manufacturer level, vertical territorial and exclusive dealing restraints may be used to facilitate the interdependent pricing of the oligopolistic manufacturers. This section will first briefly review the theory of interdependent pricing and the preferred policy toward oligopolistic interdependence before discussing how these restraints can facilitate interdependent pricing.

An oligopoly is an industry with few sellers; it appears to be generally concluded among industrial organization economists that much of American industry is oligopolistically structured. ${ }^{205}$ In pure competition, each business

203. Comanor 1423-24.

204. See SCHERER 324-32, 341-45.

205. "Suffice it to say that there is a modest amount of activity (not more than 6 or 7 percent of gross national product) approximating pure monopoly, most of which is subject to government regulation or control; somewhat more activity approximating pure competition; and 
takes the price given by the market and need not consider additional factors relevant to the oligopolist's pricing decisions. In an oligopoly, however, each business must consider the response by its rivals to its price changes, and must also consider the effect of its price changes on overall industry supply and demand. By weighing these considerations the members of an oligopoly can achieve a greater-than-competitive price, with resulting greater-than-competitive profits, provided they are able to communicate their prices to each other. ${ }^{206}$ Each firm perceives itself as facing a demand situation in which its price cuts will be matched, preserving present industry shares at lower prices and lower profits for everyone, and its price increases will not be matched unless everyone in the industry raises the price simultaneously. ${ }^{207}$ Thus, the group comes to realize that its prices are interdependent and, if everyone raises their price at the same time, greater than competitive profits can be made and present market shares preserved. But to do this, it is essential that all members of the group be able to communicate and receive communications concerning the prices of other members of the group. If this communication can be achieved without misinterpretation, it is possible for the group to raise prices and improve profits.

Although some early cases appeared to attack market conduct resulting at least in part from oligopolistic interdependence, ${ }^{208}$ it is now generally recognized that such conduct is not illegal when consciously parallel only; that is, without agreement. ${ }^{209}$ The best reason for this policy, as stated by Professor Turner, is that to condemn oligopoly as such would be to condemn what may be noncollusive profit maximizing behavior, and it has long been a hallmark of antitrust policy that noncollusive profit maximizing behavior

liberal quantities of oligopoly and monopolistic competition." SCHERER 59. See generally J. BAIN, INDUSTRIAL ORGANIZATION 77-100 (2d ed. 1968); SCHERER 57-61; Comanor 1426-27; Jones 717-21.

206. For a discussion of the theory of oligopoly pricing, see J. BAIN, supra note 205, at 118 24; SCHERER 131-57.

207. SCHERER 145-49 discusses this theory of the kinked demand curve. See also C. FERGUSON \& J. Gould, supra note 88 , at $338-40$.

The converse of the material in the text concerns price cuts. Because all price cuts will be matched, market shares will stay the same at a lower price and everyone will make a lower profit. Thus, firms will not tend to cut price when they perceive themselves to be facing a kinked demand curve, as in an oligopoly situation. See SCHERER 147.

208. See, e.g., American Tobacco Co. v. United States, 328 U.S. 781, 789, 793, 800, 809-10 (1946).

209. "The point is that conscious parallelism is never meaningful by itself, but always assumes whatever significance it might have from additional facts." Turner, The Definition of Agreement Under the Sherman Act: Conscious Parallelism and Refusals to Deal, 75 HaRv. L. REV. 655, 658 (1962). See generally A.B.A. ANTITRUST SECTION, supra note 115, at 34-37.

The "Industrial Reorganization Act" originally introduced July 24, 1972 by the late Senator Phillip Hart, S. 3832, 92d Cong., 2d Sess. (1972), is a statement of the opposite philosophy. This bill condemns certain industry structures regardless of proof of anticompetitive conduct, presumably inferring that interdependent pricing and hence anticompetitive results will flow from those industry structures. The bill has not been adopted. 
should be encouraged. ${ }^{210}$ It has also been suggested that "pure, noncollusive oligopoly is not the problem that has been popularly depicted."211 Yet while we do not condemn oligopoly as such, we should try to discourage interdependent pricing because of its anticompetitive impact. ${ }^{212}$ Thus we require that the interdependence be truly noncollusive and we do not approve the creation of market structures which will encourage interdependence. It has been suggested that the legality of vertical territorial restraints (and exclusive dealing arrangements) should be determined, at least in part, by the independence of pricing and selling policy, the number of alternative suppliers and the need to preserve faihing companies in an otherwise concentrated industry. ${ }^{213} \mathrm{~A}$ greater number and wider distribution of sellers effectively limits oligopolistic coordination for three reasons: sellers are more likely to ignore interdependence, there is more likely to be a maverick who will not follow the interdependent price and there is less tacit understanding as to the "proper" price. ${ }^{214}$

In order to discourage interdependent pricing it is necessary to make communication more difficult, to encourage cheating on the understood price and to foster the belief that others are cheating. As discussed above, for an oligopoly to effectively achieve interdependent pricing the members must be able to communicate their prices to each other. This is done both through public announcements and through observed resale prices of rivals. Yet in an oligopoly there is a strong incentive for individual members of the oligopoly to cheat. If all other members maintain a high price, then one price cutting member can achieve substantial additional sales and, consequently, increase profits with a secret price reduction. ${ }^{215}$ To the extent that the price reductions can be kept secret, there is a relative delay in the retaliatory price cutting by rival members of the oligopoly. ${ }^{216}$ Thus, to the extent that secrecy in price cuts can be achieved, cheating and a general lack

210. According to Professor Turner:

[T] can fairly be said that the rational oligopolist is behaving in exactly the same way as is the rational seller in a competitively structured industry; he is simply taking another factor into account, which he has to take into account because the situation in which he finds himself puts it there.

Turner, supra note 209, at 665-66. Professor Turner goes on to conclude that whether this kind of pricing is called interdependent or not, it should not be held illegal without further proof of an agreement. Id. 671-73.

211. Dirlam \& Kahn 33.

212. Comanor 1436-37. Professor Turner refers to this as a "containment" policy in discussing parallel exclusionary practices as potential monopolization problems. Turner, supra note 209, at 677-78. KAYSEN \& TURNER 124-27 reflects the same policy in dealing with vertical integration and horizontal merger cases which focus on market shares.

213. Minnesota Note 862 focuses on independence of pricing; Preston 521-23 focuses on the number and strength of other suppliers. THOMPSON 117-21 notes that there is a greater need to preserve failing companies in an oligopolistic industry.

214. SCHERER 183. See generally id. 183-212.

215. Id. 160 .

216. Id. 208. 
of trust among members of the oligopoly to maintain the oligopolistic interdependent price will be encouraged. It has been noted that "[o]ligopolistic coordination is a fragile thing. A misinterpreted price cut may induce an aggressive reaction which in turn leads firms to abandon their restraint and engage in price warfare."217

To achieve coordination, individual firms must be able to reassure their rivals that they are not cutting prices and the rivals must be able to assure themselves, through observed retail prices, that there is no price cutting taking place. This happens in spite of the above-discussed incentives to cut price if all firms act on their interdependence. In order for oligopolistic rivals to maximize group profits they must be able to calculate the joint profit maximizing price. "[I]n markets where oligopolistic elements are present, some ignorance and uncertainty about the behavior of rivals is an important competitive element in the market, since it prevents 'rational' oligopolistic calculation leading to joint maximization of profits." 218 Thus, we must evaluate the propensity of vertical restraints to encourage or discourage oligopolistic behavior by evaluating their tendency to facilitate communication among rivals and discourage cheating on the oligopolistic price, along with their ability to foster or hamper the existence of some ignorance or uncertainty about behavior of rivals.

Viewed by these standards, vertical territorial restraints are suspect when used in an oligopolistically structured manufacturing industry. Vertical territorial restramts encourage the communication necessary for interdependent pricing by restricting intrabrand competition, and thereby making it easier for a manufacturer to ensure that the retail price on his product is at or near the price that he wishes it to be. ${ }^{219}$ Thus the manufacturer communicates his price to his rivals and reassures them that he is behaving in a way to maximize group profits. In the extreme case, the manufacturer can raise his price enough to force the distributor to charge at least a set price to earn an adequate markup. While this control is not absolute, the tendency of vertical territorial restraints is to prop up the general price structure in an industry which is concentrated at the manufacturing level.

Similarly, vertical territorial restraints discourage cheating. If rivals know each is primarily responsible for the retail price of his product, cheaters can be detected by observing retail prices. Any change in the retail price will be readily observed and retaliation will be forthcoming. Because the individual members know that retaliation will be forthcoming, they are much less likely to cut prices. By the same mechanism, the uncertainty about rivals' behavior and response to price changes is also discouraged by

217. Id. 153.

218. KAYSEN \& TURNER 150.

219. Baker 541 . 
vertical territorial restraints. One knows what the rival's response is by observing what his price at the retail level is and, consequently, the oligopoly can respond appropriately. ${ }^{220}$ Thus, vertical territorial restraints will have a tendency to facilitate the solution to an oligopolistic seller's interdependence problems and, consequently, will support noncompetitive price structures in a concentrated industry.

It has been argued that vertical restraints do not increase market power over that held by the monopolist or oligopolist at any individual level. ${ }^{221}$ However, to the extent that these restrictions facilitate the solution to an oligopolistic seller's interdependence problems, they add to effective exercise of manufacturer level market power. Also, vertical territorial restraints permit the characteristics of a concentrated national manufacturing market to be reflected in the practices of local distribution markets. ${ }^{222}$ It has been argued that in the case of a monopoly this has no negative effect on competition: first, because the monopolistic entity could make a full monopoly profit at the manufacturing level and is merely taking it at a different level, and second, because the contractually integrated enterprise makes its greatest profits by maximizing profits at each level. ${ }^{223}$ However, when this reasoning is applied to the oligopoly situation, it overlooks the fact that these restraints can encourage successful interdependent pricing and thereby be a source of increased market power. Thus, while these restraints may not create a concentrated structure at the manufacturing level, ${ }^{224}$ they do create market power by facilitating the interdependent conduct of an oligopolistic structure. Therefore, these restraints must be considered seriously suspect where they are used in the context of the manufacturer level oligopoly.

Vertical exclusive dealing arrangements also have the effect of encouraging interdependent conduct on the part of oligopolistic manufacturers through much the same mechanism. These restraints tend to channel and limit competition, especially price competition. ${ }^{225}$ The mechanism for encouraging communication, discouraging cheating and limiting ignorance

220. Id.

221. Bork II 402. Posner 283-85 does not treat creation of market power as a reason for use of these restraints. Carstensen 787-89 argues persuasively that the static analysis of Bork overlooks the dynamic power-creating potential of these restraints.

222. Comanor 1427; Zimmerman 1185.

223. Bork II 470-71. The same argument is made concerning vertical integration in Bork, Vertical Integration and the Sherman Act: The Legal History of an Economic Misconception, supra note 184, at 195-97.

224. Concerning the similar problem of vertical integration, Professor Phillips has stated:

It has been shown that a consecutive series of vertically related and independently operated monopoly-monopsony firms results in higher prices, lower output and, paradoxically, lower joint profits than would a single, vertically integrated monopoly. It also is amply demonstrated-and not inconsequential-that vertical integration does not create monopoly power where no such power exists in at least one of the stages over which the integration occurs.

Phillips 573.

225. DirLAM \& KaHN 184-85. 
and uncertainty about rival behavior in response to price changes is the same as that for territorial restraints. While the same objections have been raised to this argument as were discussed above, ${ }^{226}$ it is here again submitted that these restraints can create additional market power by facilitating the solution to the oligopolistic seller's interdependence problems. Indeed, an exclusive dealing arrangement increases manufacturer control over the retailer by eliminating other products on which the retailer can concentrate sales effort if the manufacturer price is too high and by increasing the cost to the retailer of manufacturer disapproval, which may be manifested by the termination of business from the manufacturer. Should the retailer lose the manufacturer's business, he would be forced to start from scratch in atteinpting to develop consumer acceptance of a different product. Where all products in the market are manufactured by members of the oligopoly, the retailer will not likely be successful in finding another product over which he has greater price control. Also, exclusive dealing arrangements are less justified where the manufacturer has a high market share because there is less interbrand competition and thus less need for this competitive edge. ${ }^{227}$ In addition, exclusive dealing arrangements increase the chance of an oligopoly's interdependent conduct being thrust into the distribution level, the anticompetitive results of which were discussed above. ${ }^{228}$ Thus, exclusive dealing arrangements are also seriously suspect when they exist in the context of a concentrated manufacturer market. When used with territorial restraints in this market structure, exclusive dealing arrangements reinforce the tendency to facilitate oligopolistic interdependent conduct.

It should be noted in passing that the propensity of resale price maintenance agreements to facilitate solutions to an oligopolistic seller's interdependence problems is even greater. ${ }^{229}$ Resale price inaintenance makes the partial control of territorial and exclusive dealing arrangements much more complete and, consequently, enhances communication, discourages cheating and more effectively eliminates ignorance and uncertainty. Resale price maintenance agreements are generally held to be per se illegal except for those falling in the narrow rule of United States v. Colgate \& Co..$^{230}$

226. See authorities cited in notes 221 \& 223 supra.

227. Harvard Note 833-34.

228. Id. 834; see text accompanying notes 219-24 supra.

229. Jordan, supra note 46, at 120-22; Columbia Note 498 -n.12; Harvard Note 800-01; Indiana Note 804. Contra, Posner 293-94, where it is argued that the justifications are the same. Even Professor Bork recognizes that resale price maintenance agreements can give greater manufacturer control under certain circumstances, but would presumably argue that this does not create anticompetitive results. Bork II 453.

230. 250 U.S. 300 (1919). Under the holding of this case, a manufacturer may specify in advance the price at which the goods may be resold and may refuse to make further sales to a retailer who does not comply. Id. at 306-07. 


\section{F. Other Reasons or Justifications.}

Other reasons for the use of vertical territorial restraints have been suggested. This section will discuss four of those reasons: retailer cartels, restraints as an alternative to vertical integration, restraints to accomplish price discrimination and restraints used to control reseller image.

Vertical territorial restraints can be imposed as a means of increasing price and reducing output in response to a retail level cartel. Such cartelbased restraints would have the effect of reducing competition among the retailers of the supplier's product. ${ }^{231}$ However, it is not likely that imposition of these restraints in response to retailer cartel pressures is in the supplier's self interest; the cartel seeks to raise price even at the expense of national sales and the supplier seeks the greater profits usually associated with greater sales. ${ }^{232}$ Because such horizontal agreements are clearly illegal at present, the problem is to sort out the retailer cartel cases from the cases where there may be some legitimate reason for imposing the restraint. It has been suggested that the enforcement agencies will be able to distimguish between the retailer cartel situations and vertically imposed restraints. ${ }^{233}$ This is because retailer cartels will have to be larger, and will have to be reasonably public to accomplish organization, admimistration and policing, and it is likely that coerced manufacturers will complain. ${ }^{234}$ In American industry the manufacturer or wholesaler is generally the more powerful member of the distribution chain, and retailing is typically a relatively small, localized and less profitable business. ${ }^{235}$ For these reasons it does not appear likely that there will be insurmountable problems in identifying such cartels when they are in fact the motivation for vertical territorial restraints.

Vertical territorial restraints are sometimes justified as an alternative to vertical integration. If not permitted these restraints, arguably suppliers will vertically integrate to achieve the controls that they need to operate in today's market, where there are great deinands for control. ${ }^{236}$ However,

231. Posner 283-85. Professor Posner does note that this theory has not been established empirically. Id. 285.

232. Stone 299-301. Of course, the greatest number of sales by the manufacturer will not always coincide with the greatest profits and, in the final analysis, the manufacturer seeks greater profits rather than greater sales. However, the manufacturer is unlikely to profit from the effects of a retailer cartel in that it will not raise his price, but should reduce his sales. See generally Zimmerman 1184.

233. Wheeler, A Reexamination of Antitrust Law and Exclusive Territorial Grants by Patentees, 119 U. PA. L. REV. 642, 662-65 (1971), argues that this distinction can be made in the patent cases because the retailer cartel will be highly visible.

234. Bork II 405-10.

235. See authorities cited in note 237 infra.

236. See, e.8. , Keck, supra note 14, at 178, 189-91 (noting that Schwinn did in fact vertically integrate); Pollock, supra note 10, at 569-70; Wade, Some Antitrust Problems in Terminating Franchises, 44 SAINT JoHN's L. REV. 23, 35 (1969); Zimmerman 1183. The inconsistent treatment of vertical integration and vertical restraints is noted unfavorably in Bork II 472-73. Of 
several characteristics of the different vertical levels make this relatively

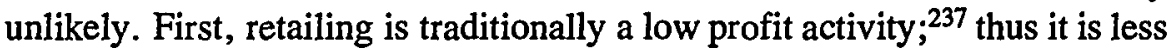
attractive to manufacturers considering new investment. Second, the product mix required at the retail level is frequently different from that required at the manufacturing level, again making vertical integration less attractive. ${ }^{238}$ Third, the high cost of vertical integration, including high promotional expense and high inventory and labor expense, will frequently make it very undesirable. ${ }^{239}$ Finally, various labor problems may make vertical integration undesirable; among these are the great difficulty in achieving the same degree of local responsibility and entrepreneurial effort from employees as from local businessmen, successful compliance with labor laws and the supervisory problems of managing a far-flung sales force. ${ }^{240}$ It has been suggested that those who can afford to integrate vertically will do so anyway, regardless of the law of territorial restrictions. ${ }^{241} \mathrm{~A}$ recent analysis which supports this suggests that vertical integration is undertaken to internalize and control first, the risk of responding to problems when the supplier possesses only imperfect information; second, enforcement costs of contracts governing vertical relationships; and third, an unequal distribution of information. ${ }^{242}$ To the extent that this position is correct, vertical integration is not likely to be either caused or restrained by the law governing vertical territorial and exclusive dealing restraints. Thus there seems little reason to conclude that the use of vertical restraints can be justified as an alternative to vertical integration. ${ }^{243}$

Vertical territorial restraints can also be imposed to facilitate price

course, where the competitive problems are truly different, inconsistent treatment is not inappropriate. See SYMPOSIUM 47-48, which makes this point in discussing why different rules may be needed for exclusive dealing and exclusive territorial arrangements.

237. According to Professor Enis, "retailers' gross margins fluctuate . . . but average 35 to 40 percent. Expenses consume most of the gross margin, leaving middlemen with net profits generally below those of other types of profit-seeking organizations." ENIS 471-72. See also Comanor 1435 .

238. Comanor 1435; Zimmerman 1186-87. To operate at efficient levels of production, vertical integration may also require horizontal expansion through merger. MCCARTHY 310-11. This horizontal merger may well be illegal also.

239. Dalrymple \& Parsons 403, 406, 416; Jordan 111-13; Preston 512; Zimmerman 1186. SYMPOSIUM 55-56 notes that manufacturers were using franchising more than forward vertical integration prior to Schwinn. Harvard Note $834^{-}$concludes that most firms find advertising, research and development, and backward integration to be better uses of their capital.

240. Symposium 55-56; Comanor 1435; Preston 512; Zimmerman 1186; Harvard Note 834.

241. SYMPOSIUM 55-56; Jones 720-21.

242. Phillips 573-76.

243. It has been argued that not all vertical integration is necessarily bad, in that vertical integration can be undertaken to secure efficiencies or for other procompetitive reasons. Id. 576-77. See also KAYSEN \& TURNER 120; Blake \& Jones, supra note 184, at 390; Comanor 1436. It has also been argued that vertical integration is not a useful analytical concept for antitrust law. See generally Bork, Vertical Integration Under the Sherman Act: The Legal History of an Economic Misconception, supra note 184. 
discrimination. ${ }^{244}$ For a seller to practice price discrimination profitably three conditions must exist. ${ }^{245}$ First, the seller must have some market power. To the extent that these restraints increase market power, ${ }^{246}$ they help satisfy this condition. Second, "the would-be discriminator must be able to segregate its customers into groups with different price elasticities of demand, or into discrete classes with varying reservation prices . . . ."247 To the extent that these restraints decrease intrabrand competition they help segregate customers into these groups. Thus, the restraints can aid in the satisfaction of this condition. Third, there must exist some restraints on low price customers who would sell to high price customers. While direct customer restraints would accomplish this more effectively, the reduced intrabrand competition of territorial and exclusive dealing restraints also facilitates satisfaction of this condition.

Once it is determined that these restraints do facilitate price discrimination, this result must be evaluated in terms of economic welfare. This question appears to be impossible to answer in the abstract and may be very difficult to answer in any concrete fact situation. Price discrimination can, as an abstract proposition, improve allocation of resources by increasing production on the part of those with market power. ${ }^{248}$ Second, although price discrimination does accomplish a redistribution of income from the discriminatee to discriminator, an evaluation of this involves value judgments which can be neither controverted nor supported as an abstract policy matter. ${ }^{249}$ Finally, systematic price discrimination tends to support noncompetitive market structures, whereas unsystematic discrimination can tend to break up those structures and can generally be a way of competing. ${ }^{250}$ Therefore, it is not possible to say whether the facilitation of price discrimination is good or bad and a detailed discussion is beyond the scope of this Article. ${ }^{251}$

Finally, these restraints have been justified as a way of keeping the manufacturer's products out of the hands of "undesirables," confining the

244. Price discrimination by vertical restraint is limited to the case where differing elasticities of demand "are created by the fact that the customers to be separated place different values upon the product." Bork II 417. See also Comanor 1433-34; Jordan 125-29.

245. SCHERER 253.

246. See text accompanying notes 182-230 supra.

247. Reservation prices are the highest prices buyers will pay for any specific unit of output. SCHERER 253.

248. Id. 258-59. See also Jordan 129. Bork, Vertical Integration Under the Sherman Act: The Legal History of an Economic Misconception, supra note 184, at 197-98, discusses this proposition in the context of vertical integration. Compare Comanor 1433-34 with Bork II 417.

249. SCHERER 257-58.

250. Id. 261-62.

251. The Robinson-Patman Act appears to imply a national policy discouraging price discrimination where that discrimination is not cost justified or otherwise defensible. 15 U.S.C. $\S$ 13 (1970). The advisability of this policy is the subject of continuing debate. 
products to distributors who project the image which the manufacturcr wishes for the product. ${ }^{252}$ Certainly to the extent that the manufacturer wishes to promote a particular image with his products he needs to control the kind of distributors who sell it. However, it appears that this problem can be substantially remedied with careful initial dealer selection, so that the restraints should not be justified in order to achieve this goal. ${ }^{253}$

\section{PRoposed Rule of Decision For the Courts}

Previous sections have analyzed the needs of distribution systems and the motives and justifications for the vertical territorial restraints used in them. This section will examine the rules that have been proposed for governing these restraints and conclude with a new proposed rule designed to give proper weight to the legitimate needs of businesses in establishing effective distribution systems consistent with the needs of competitive market conduct and market structures.

While some commentators have favored the per se rule of Schwinn, ${ }^{254}$ the weight of the commentary has always favored a rule of reason analysis, primarily because the practices to be regulated can have either procompetitive or anticompetitive effects. ${ }^{255}$ This latter view has been decisively

252. Pogue, supra note 17 , at $288-89$. Zimmerman 1183 notes this explanation but goes on to state that the primary reason for keeping the product out of discount houses may really be to avoid the outbreak of price competition. Id. 1185.

253. Professor Bork offers three additional justifications for vertical restraints generally. First, it is possible to achieve advertising economies of scale in certain circumstances. Bork II 460-61. However, these economies should be achieved by profit maximizing firms without the need for vertical territorial restraints. Secondly, Professor Bork notes that restraints can be used to encourage information exchange, which can lead to creation of efficiencies. Bork 11 439-40. This was treated in the text accompanying notes 112-17 supra as part of the cream skimming or free ride problem. Finally, the cost of a joint facility can be shared with these restraints. Bork II 449-51. Professor Bork recognizes, however, that this will occur only in the rare case where overlapping use of the service would destroy its effectiveness. In addition, this cost sharing can be achieved with the restraint only if the facility is used for service and not for product sales.

254. Comanor 1436-38 favors a per se rule because of the anticompetitive effects of the product differentiation which can result from these restraints. Stone 314-17 favors a per se rule because he believes that the balancing process of a rule of reason will balance out in favor of the restraint so infrequently that it is not worth the trouble of administering the rule. DiRLAM \& KAHN 197 notes the difficulty of balancing interests in this area.

255. See, e.g. , Bork II 381; Day 249; Jenkins 1; Pogue, supra note 17, at 288-89; Posner 29899; Columbia Note 515; Note, supra note 6, at 149-50; Indiana Note 805. It has been argued that this rule tends to preserve small businesses, discouraging increasing concentration. See Jordan 152-55. In addition, it has been observed that the per se rule operates as an artificial barrier to firm choice of distribution procedure. Phillips 578 .

Of course, the so-called "per se" rules as applied are not nearly as inflexible as the statement of the rule would make them sound. It is generally recognized that there is some flexibility even in per se concepts for fringe area difficulties. See generally Bork I 777; Sadd, supra note 23, at 250; The Per Se Rule, supra note 23, at 780-84. For an extended discussion of the history and development of per se rules as well as the rationale behind them, see Bork 1829 . 46. 
adopted by the Court in Sylvania. ${ }^{256}$

A per se rule is appropriate, according to the traditional criteria, when the restraints in question are so anticompetitive that they can never be found reasonable because no sufficient justification could ever be offered. ${ }^{257}$ The focus must be on the procompetitive potential of a questioned practice. As discussed in Section III above, these restraints can be procompetitive by serving the needs of economic efficiency and effective competition among distribution systems. The practices encourage coordination and thereby assist a distribution system in competing with others. Similarly, they can help individual firms compete and, thus, improve the competitive structure and the state of competition. ${ }^{258}$ These practices accomplish this by encouraging provision of pre-sale services and post-sale services, and improving dealer loyalty. However, they can also have anticompetitive effects by erecting or strengthening barriers to entry, facilitating oligopolistic interdependent pricing and encouraging the formation of dealer cartels. ${ }^{259}$ As the Court correctly ruled, a per se analysis is therefore not appropriate for these practices, since they may be either procompetitive and efficiency-creating or anticompetitive.

In the traditional antitrust dichotomy, questions which are not appropriate for a per se rule are to be answered with a rule of reason analysis. However, it is submitted that such an open-ended analysis is not appropriate for evaluating vertical territorial restraints. Such an analysis would require an unsophisticated court to evaluate questions which are too open-ended, and consequently, would not produce satisfactory results. In a recent article demonstrating the failure of courts to make effective rules dealing with restraints of this sort, Professor Posner pointed out that the body of law to be dealt with in this area is simply too complex and difficult to be developed by nonspecialists. ${ }^{260}$ Accordingly, much of the "doctrinal chaos" in the antitrust field has been attributed to "(1) a failure to analyze and select the goals

256. See Sylvania, 97 S. Ct. at 2562-63.

257. "However, there are certain agreements or practices which because of their pernicious effect on competition and lack of any redeeming virtues are conclusively presumed to be unreasonable and therefore illegal without elaborate inquiry as to the precise harm they have caused or the business excuse for their use." Northern Pac. Ry. v. United States, 356 U.S. 1, 5 (1958). Bork II 384 defines agreements which are per se illegal as those which eliminate competition and have no efficiency creating potential. This view can be harmonized with the more traditional statement through the understanding that an agreement with efficiency creating potential makes the firm using it a better competitor and, consequently, improves competition.

258. See notes 92-253 supra and accompanying text. See also SCHERER 510.

259. See notes 182-253 supra and accompanying text.

260. Posner 326. The approach of this Article is quite similar to that advocated by Professor Bok for exclusive dealing arrangements. See generally Bok, The Tampa Electric Case and the Problem of Exclusive Arrangements Under the Clayton Act, 1961 SUP. CT. REv. 267. 
or values the law may properly serve; and (2) a failure adequately to appreciate the nature of the economic phenomena with which the law must deal."261 To decide these cases through a rule of reason analysis, a court needs not only familiarity with the law, but also a minimal ability to understand and evaluate the arguments of economic theorists and apply them to specific items of proof offered to the court. Most courts are simply not sufficiently sophisticated in dealing with this kind of material to do an adequate job.

The problem is compounded by the open-ended nature of the questions raised by the cases, in that the court is required to make an independent analysis of all the effects on competition of a particular practice in a particular market. ${ }^{262}$ The court must determine a priori what difference product differentiation, market concentration, exclusive dealing arrangements, entry barriers and other structures and conduct make, and then look for particular anticompetitive effects in this market. Next, the court must be able to determine what justifications are possible for the practice, again as an a priori theoretical matter. Then the court must apply the facts of the case to determine if the theoretical justifications-the need for pre-sale and postsale services and dealer loyalty, as well as the need for system coordination-apply to the case before it. Finally, the court must balance the justification against the potential for competitive harm, a difficult prospect at best. ${ }^{263}$ Such a decisional process requires a court with great skill in using economic facts and theories and with a great deal of time for a particular case. Most courts are not able to define the issues of competitive relevance and justification with sufficient clarity to narrow the inquiry. Thus, the determination of the reasonableness of the practice is an unstructured examination. Where there is no structure to the determination of the ultimate question, there are no means of limiting proof to well-defined issues, and counsel are permitted to offer any evidence bearing on reasonableness. An unguided inquiry, characterized by unconstrained and extraneous proof, results in an unmanageable proceeding and uncertain decisions. This admittedly difficult task is undertaken where counsel are less likely to be helpful because their understanding of the law and the economics may be equally deficient. ${ }^{264}$ In addition, if an appeal is taken, the Expediting Act deprives the court of last resort of an additional lower court consideration. ${ }^{265}$

261. Bork I 777. The term "doctrinal chaos" is taken from Bork II 377. There is a definite need for articulated standards in deciding cases dealing with restraints of this type. Bork I 84047. It has been observed that one of the primary reasons for the Schwinn decision was the unwillingness of the court to engage in the weighing required by a rule of reason analysis. McLaren, supra note 8, at 143-44 and authorities cited in note 11 supra.

262. See Indiana Note 806 for a discussion of the difficulties frequently encountered in applying the rule of reason.

263. See Bork II 387-90. See generally SYMPOSIUM 30-31.

264. Posner 326.

265. McLaren, supra note 8 , at 143-44. 
The difficulty and uncertainty of litigating straight rule of reason questions make them a poor priority choice of enforcement agencies in allocating scarce resources; thus, fewer of these cases will be brought. The lack of sophistication of courts and the open-ended nature of the questions posed by the rule of reason make such an analysis an ineffective rule for deciding cases involving vertical territorial restraints. One purpose of this Article is to provide a structure for deciding these cases so that courts will not need to be economic theorists, will have manageable questions to deal with, and can focus on answering the kind of questions for which they are equipped.

A third possible rule applicable to these restraints is a rule of presumptive illegality. This is the rule that the Justice Department argued for in the Schwinn case as a midpoint between a per se rule and a rule of reason. ${ }^{266}$ Such a rule has been recently proposed by former Assistant Attorney General Donald Baker. As proposed it would presume illegality of these restraints when they are used in the following situations: where the manufacturing market is concentrated; where the market is concentrated at the dealer level; where the restraints are designed to protect manufacturers or dealers from price cutting; where the restraints are combined with exclusive dealing; and in other areas. ${ }^{267}$ Possible defenses which would rebut the presumption include unusual necessity to protect manufacturer goodwill resulting from complex product or unusual service requirements, products which involve special risks to health or safety, and facilitation of entry into new markets where needed as a dealer incentive. ${ }^{268}$ The test would also require a showing by the restraining party that the restraint was the least restrictive alternative. Unless the presumption is rebutted, a restraint would be found illegal regardless of how it is imposed. ${ }^{269}$ The difficulty with this approach is that it might invalidate restraints which create efficiencies or are otherwise justifiable as procompetitive. To avoid making the use of these restraints illegal in such situations, defendants should be permitted to rebut the presumption of illegality by arguing that a restraint creates efficiencies or is otherwise procompetitive and justifiable. However, such defenses would permit each side to present a full-blown case concerning the effect of the restraint on competition and justifications for the restraints. The court would therefore be forced to face open-ended questions like those raised under the rule of reason, with the same inherent difficulties. While the questions raised by the presumptive illegality theory may be more specific

266. SYMPOSIUM $31,36$.

267. Baker 543-46. DiRLAM \& KAHN 178 says that the presumption of the antitrust laws should be against restraints where the industry is oligopolistically structured or entry is difficult.

268. Baker 546-47.

269. Id. 547. 
than a simple determination of the "unreasonableness" of the restraints, they are still extremely broad; the test fails to limit the admissible evidence, and does not give the court more manageable issues to consider. The net effect would probably be to reverse the burden of proof. This reversal is a sensitive question, however, because the burden of proof is so often determinative in rule of reason cases. As a policy matter it seems appropriate to require the government or private plaintiff to prove a likely anticompetitive result before the defendant has to respond, particularly when dealing with a practice which can also be procompetitive. As presently stated, the rule of presumptive illegality does not bring into focus the relevant factors to be evaluated in determining the legality of these restraints and does not limit proof on those questions. The proposed rule of this Article will attempt to do so. ${ }^{270}$

Mr. Baker does not call his rule one of presumptive illegality, but rather a "structured rule of reason." The rule proposed here is also a structured rule of reason, but provides more structure. Its purpose is to limit the court's evaluation to manageable and workable factors. This rule will articulate those factors distinguishing procompetitive from anticompetitive interests, motives and effects. The purpose of the rule is to relieve courts of the requirement that they be economic theorists; through application of the criteria discussed herein, it will be possible to identify specific conduct, market structures, market characteristics and product characteristics which correlate closely with the determination that these restraints are procompetitive or efficiency creating, and to distinguish such situations from those in which restraints are anticompetitive. Thus, the theoretical work is done for the court and it need not decide as an a priori matter what factors are important. The court is only required to evaluate specific industry, market and product characteristics to determine when the restraints should be permitted and when they should be prohibited. The following six factors should be evaluated by the court to determine the legality of these restraints.

The existence of effective interbrand competition is the first factor. While this is a broad question, it is not a totally open-ended one. In establishing whether effective interbrand competition exists, it is suggested that the court focus first on the cross-price elasticity of 'demand. ${ }^{271}$ If there is substantial cross-price elasticity of demand then it is quite likely that there are effective competitors for the product in the market. Next, the court can

270. Of course, to the extent that the following questions are incorporated in the presumptive illegality test as bases for the presumption or as defenses to it, the rule of presumptive illegality and the rule to be proposed below are similar.

271. See, e.g., United States v. E.I. duPont de Nemours \& Co., 351 U.S. 377 (1956).

Cross price elasticity of demand is a measure of the sensitivity of change in quantity sold of product $X$ to change in price of product $Y$. It is expressed by the following formula: $\%$ change in Quantity of $X$ divided by $\%$ change in Price of $Y$. 
look to profit ratios. While unusually high profits in the short term are not indicative of the absence of effective interbrand competition, long term, unexplained and abnormally high profits are one indicator of a lack of such competition. Third, the court should evaluate the innovation and progress of the industry in light of what has been achieved compared to what the court finds to have been possible. While this is not as precise a question as one would prefer, comparison to foreign models and expert opinion on the potential for innovation and product development should be helpful. Fourth, the court should attempt to determine if there is a well recognized, long-term lack of overall efficiency in the industry. Here again the question is not completely specific, but is believed to be manageable. The court should not evaluate whether the industry is as efficient as it could be, but determine only if it is notoriously inefficient or is well known for its excess capacity; such characteristics are indicative of a lack of effective interbrand competition. Of course, these criteria should not be exclusive. However, if the court focuses on them, the burden should be on the parties to demonstrate the relevance of any other criteria tending to prove or disprove effective interbrand competition. As discussed above, where there is effective interbrand competition, distribution systems will have a legitimate interest in using these vertical territorial restraints as competitive tools against other distribution systems. ${ }^{272}$ The restraints are much more likely to be justifiable restrictions used to induce needed pre-sale selling services, post-sale services and distributor loyalty, ${ }^{273}$ rather than being used as an effective barrier to entry or to facilitate interdependent pricing. ${ }^{274}$ Where no effective interbrand competition exists, the converse of each of these conclusions is suggested and the courts should view the restraints prohibitively.

Industry concentration level is the second factor which the court should evaluate. In many circumstances, the existence of effective interbrand competition will be related to industry structure. Specifically, interbrand competition will not survive interdependent pricing, a problem likely to arise only in a concentrated industry; ${ }^{275}$ thus the restraints should be particularly suspect in that situation. Of course, if effective interbrand competition, particularly price competition, can be established im spite of a concentrated and potentially uncompetitive industry structure, such proof would dispel

272. See notes $45-91$ supra and accompanying text.

273. See notes 92-181 supra and accompanying text. It should also be noted that effective interbrand competition will limit provision of more services than the consumer wants by bidding out excess services.

274. See notes 182-230 supra and accompanying text.

275. See notes 205-30 supra and accompanying text. As discussed immediately above, where no interbrand competition occurs, there is less need for these restraints as a way of competing effectively with other distribution systems, less need for the restraints as a means of encouraging pre-sale and post-sale services and dealer loyalty, and greater probability that the restraints are being used as barriers preventing entry into the market. 
concerns arising from the use of these restraints in a concentrated industry. The existence of such interbrand competition can be established by a showing that independent and not interdependent pricing occurs in the industry. However, the existence of effective interbrand competition, if proved, would have to be maintained for this defense to remain valid. Concentration of the industry should be evaluated at both the manufacturer and the distributor levels, although generally the latter level is less likely to be concentrated in most industries. ${ }^{276}$

The third factor to be evaluated by the court is the existence of product differentiation that is based on image advertising rather than product quality, function, service or price. This factor is also related to the existence of effective interbrand competition. As a measure of the extent of product differentiation, Bain suggests an examination of the "sensitivity of the market share of the individual franchisee [distributor] to price variations, which can be estimated by comparing the franchisee's [distributor's] market share before and after a price change." 277 A similar analysis should be made at the manufacturer level to determine the existence of differentiation there. The test of cross-price elasticity of demand, also used to define the market, is not inconsistent with this. If the market is defined as only one product because of the absence of cross-price elasticity of demand, then effective product differentiation has probably been achieved because no other products are offered in the relevant market. While the same test is used in determining market definition and extent of differentiation, the determinations are consistent. In addition to cross-price elasticity of demand, the court should consider relative advertising expense compared to other businesses in the industry and the other industries producing similar products. ${ }^{278}$ Also,

276. Most distributors are small enterprises which are relatively less profitable. Businesses in this situation normally lack the ability to bar entry or otherwise encourage concentration and are less likely to be in a concentrated market.

Once the extent of concentration in a given industry is calculated, the court will have to decide how much concentration it will permit before it views vertical territorial restraints prohibitively. While one must be suspicious of any rule which predicates illegality on concentration statistics alone, some guidance can be gleaned from Kaysen and Turner's definitions: "Loose oligopoly," is defined as "a small number (less than twenty) of firms supplying 75 percent of the market, with no one supplying more than 10-15 percent and a fringe of smaller firms supplying the rest," while "tight oligopoly" is defined as "a very small number (eight or fewer) firms supplying 50 percent of the market, with the largest firms having a 20 percent or higher share, and with or without a fringe of small suppliers." KAYSEN \& TURNER 72. These categories appear to provide some guidance as to when an industry should be considered concentrated. J. BAIN, supra note 205, at 464 offers this conclusion: "Tentative indications are that if seller concentration exceeds that in which the largest eight sellers supply from two-thirds to three-fourths of the output of an industry, there is a strong disposition toward significant monopolistic price-raising and excess profits." SCHERER 158-212 focuses on conditions facilitating and limiting oligopolistic coordination in Chapters 6 and 7, reinforcing the idea that an evaluation of independence and interdependence of pricing must be made in eaeh case.

277. THOMPSON 100.

278. See generally SCHERER 341-44. 
differences in actual quality, product function, product service, or price should be considered as ameliorating circumstances. If these exist, effective differentiation is still present, but it is the kind of product improvement that serves as an element of competition that should be encouraged rather than discouraged. ${ }^{279}$ Where image-based differentiation exists, there is less need for vertical territorial restraints to induce pre-sale and post-sale services and dealer loyalty, and greater potential for entry barriers resulting from such restraints. ${ }^{280}$

The fourth factor to be evaluated by the court is the existence of barriers to entry. Specific barriers which can result from these restraints are foreclosure, increased capital requirements and product differentiation. In evaluating whether foreclosure has in fact occurred, the court will have to look to whether new or expanding entities in the market have access to existing distribution organizations or whether distribution of the product could be accomplished only by creating new distribution organizations. This will lead the court to ask questions concerning the related entry barrier of increased capital requirements. Do the restraints result in foreclosure which necessitates multi-level entry? If so, is capital likely to be available to make the multi-level entry? Is it possible to develop a distribution organization which can raise its own capital? Whether product differentiation exists as a barrier to entry should be evaluated here the sanie way as it was above. Of course, if there are additional barriers to entry, not created by the restraints, the net effect of the restraints may be to hamper interbrand competition by supporting previously existing barriers. If new entry has been tried unsuccessfully, and no other explanations for the failure are available, this is persuasive evidence that real barriers to entry exist and that restraints should be viewed with suspicion. However, the failure to prove unsuccessful attempted entry does not necessarily establish that there are no barriers to entry. Indeed, if the barriers are extremely high, new entry will not even be attempted because any rational firm would realize the probability of failure. The court should evaluate the facts in each case in light of these considerations to determine whether the restraints create or foster barriers to entry.

The fifth factor, the promotion of newcomers and new products, is related to barriers to entry. Virtually every writer in the area would permit the restraint to facilitate new entry if used by a newcomer in the market or by the manufacturer of a new product. ${ }^{281}$ While this one factor should not override extremely suspicious evidence produced by analyzing all the other factors, it is certainly an extremely strong justification for the restraints.

279. Comanor 1422-25. Professor Comanor discusses permitting differentiation based on "superior skill, foresight, and industry."

280. See notes 200-04 supra and accompanying text.

281. See notes 118-24 supra and accompanying text. 
Finally, the existence of exclusive dealing requirements in combination with vertical territorial restraints should be seriously suspect. Where used simultaneously, it is less likely that both restraints are actually needed to achieve an effective competitive position for the distribution chain or that both restraints are needed to encourage pre-sale and post-sale services and dealer loyalty. ${ }^{282}$ In addition, the existence of the restraints in concert makes the possibility of substantial entry barriers much more likely and makes possible the even greater facilitation of interdependent pricing. ${ }^{283}$ Where the exclusive dealing restraints are used with vertical territorial restraints, the court should insist on exceptionally strong justification based on the characteristics of the product and the demands of the consuming market. Absent such justification, a combination of these restraints is seriously suspect.

By focusing on the six factors enumerated above, the court can evaluate the restraints according to the legitimate needs of a distribution system, their justification in providing needed services and loyalty, and their entrybarring and interdependent pricing potential. ${ }^{284}$ Of course, other evidence indicating the efficiency-creating or procompetitive effect of these restraints should also be evaluated by the courts. Similarly, an exceptionally great need for pre-sale or post-sale services or sales stability resulting from product characteristics or market characteristics should be evaluated. However, the courts should insist on a sound and comprehensible theoretical justification of such evidence and its relevance before permitting the evidence to be heard. The burden of proof of both the relevance of the evidence and the ultimate facts should be placed on the party seeking to sustain the restraints. Thus the parties should not be given carte blanche to introduce any and all evidence but should be restricted to these six factors unless they can demonstrate why an exception should be made in the particular case.

This proposed rule can be applied retrospectively to the facts of the recent Sylvania case. Although the record is not as extensive as one would like, Sylvania's unchallenged statement that there were one hundred retailers selling twenty-five brands of television sets in the Sacramento area in 1965 is a strong indication that effective interbrand competition existed. ${ }^{285}$

282. See notes 92-181 supra and accompanying text.

283. See notes 182-230 supra and accompanying text.

284. As discussed in the text accompanying notes 231-53 supra, the restraints may also be used to enforce retailer cartels, as an alternative to vertical integration, to accomplish price discrimination and to control the "image" of resellers. Where the restraints are used to enforce retailer cartels they should be per se illegal. The other justifications offered appear to be unlikely, of little competitive significance, or of indeterminant competitive consequences. See notes 231-53 supra and accompanying text.

285. Brief for Respondent in Opposition to the Petition for Certiorari $7 \mathrm{n} .5$; Brief for Respondent 11 n.8. Continental contended that no effective intrabrand competition existed. Brief for Petitioner 7-8, 35; Reply Brief for Petititioner 4. This was disputed by Sylvania, Brief for Respondent 46, and by the court of appeals, 537 F.2d at 1001 . 
If this conclusion is correct, then the restraints are neither likely to be used to accomplish anticompetitive results, nor to be effective in doing so. Second, the industry concentration level is high, but does not appear to be prohibitively so. ${ }^{286}$ While Continental once alluded to differentiation based on image, no support for this conclusion is offered in the parties' briefs or in reported opinions. ${ }^{287}$ Similarly, entry barriers in the form of economies of scale are mentioned but not supported by briefs or reported opinions. ${ }^{288}$ Also, Sylvania is not a newcomer, nor does it have a new product. Sylvania tried to argue that it was failing in that it would have left the television business if it could not expand its market share; all the testimony on this point was self-serving and, hence, suspect. ${ }^{289}$ In any event, an otherwise healthy firm which may decide to leave a business simply because it is not sufficiently profitable is not a failing firm within the policy of the Sherman Act. Finally, the location clause was not used in conjunction with exclusive dealing agreements and retailers typically carried products of several manufacturers. ${ }^{290}$ Thus it appears that, absent an extraordinary showing of competitive harm, the restrictions used by Sylvania would have been upheld under the proposed rule, primarily because of the existence of effective interbrand competition.

The strengths of the proposed rule are also illustrated upon examination of the Sylvania opinions. While the available record gives an indication that the location restrictions would have been upheld, this conclusion is not certain because the parties and courts involved did not focus on the proper questions (and consequently did not always generate an adequate record on them). The proposed rule will focus the dispute on the questions which are most relevant and should, thereby, miprove decision-making in this area.

This new structured rule of reason has several advantages. First of all, it focuses a non-expert court on the areas of concern which should be central in determining the competitive effect of these restraints. It relieves the trial court of the burden of being an economic theorist and permits the court to simply hear evidence on reasonably precise and manageable questions. Second, the proposed rule should exclude some of the economic evidence

286. The District Court found that Sylvania was the eighth or ninth largest manufacturer with four to five percent of the market. Petition for Certiorari 116 (Appendix B, District Court Findings of Fact No. 1). Presumably other members of the industry claimed smaller shares, possibly indicating a total industry population exceeding ten firms with strong fringe firms like Sylvania.

Of course, one would prefer to have explicit findings on the structure of this industry and the independence of its pricing. The court of appeals did refer to the structure as oligopolistic. 537 F.2d at 1002.

287. Brief for Petitioner 37.

288. Brief for Respondent 4-5.

289. Brief for Respondent 4-7.

290. Brief for Respondent 9. This fact was emphasized by the court of appeals. $537 \mathrm{~F} .2 \mathrm{~d}$ at 997, 1001. 
that is now offered to answer the unstructured reasonableness test of an open-ended rule of reason. This should make for shorter trials, a more manageable record for review and consequently, overall easier enforcement and greater certainty in the law. Greater certainty results because businessmen and their attorneys would know the factors which the court will consider important in evaluating the restraints. This makes it easier for them to evaluate restraints independently and, accordingly, makes it less likely that restraints will be used in situations in which they cannot be successfully defended in court. A recurring criticism of the rule of reason test under the antitrust laws is that the businessmen whose conduct the law seeks to control and channel cannot evaluate their conduct prior to engaging in it. The proposed rule should provide greater certainty while maintaining the flexibility necessary to sort out procompetitive and anticompetitive use of these restraints.

Finally, the suggested rule can be developed more easily and with greater precision in response to increasing knowledge and understanding of the industrial organization of the country, and the related economic theories. If future research establishes that one of the specific factors discussed above does not correlate well with the determination of the procompetitive and anticompetitive consequences of these restraints, that particular factor can be removed from the list. Similarly, if research indicates that other factors should be considered, those can be added to the relevant group. The relatively inexpert trial court is not required to evaluate this research and make these public policy decisions based on the conclusions of economists and others. This can be done by the Federal Trade Commission, appellate courts or Congress. While these bodies are not infallible, they have at least the potential to be relatively more expert in dealing with these matters than the trial courts who must now perform this function. The proposed new rule forces the rule-changing body to focus on the questions to be answered and provides an analytical structure for approaching those questions. 